\title{
Turist Rehberliği Tezsiz Yüksek Lisans Eğitimi: Dersler ve Akademisyenler Üzerine Bir Araştırma
}

\section{Non-Thesis Master's Education in Tourist Guidance: A Study on the Lectures and Academicians}

\author{
Öğr. Gör. Serkan AK \\ Kütahya Dumlupınar Üniversitesi, Çavdarhisar Meslek Yüksekokulu, Türkiye \\ Kütahya Dumlupınar University, Çavdarhisar Vocational School, Turkey \\ E-Mail: serkan.ak@dpu.edu.tr
}

Prof. Dr. H. Hüseyin SOYBALI Afyon Kocatepe Üniversitesi, Turizm Fakültesi, Türkiye Afyon Kocatepe University, Faculty of Tourism, Turkey E-Mail: hsoybali@aku.edu.tr

$\ddot{O} \mathbf{z}$

Amaç ve Önem: $\mathrm{Bu}$ araştırmanın amacı, Türkiye'deki turist rehberliği tezsiz yüksek lisans programlarında yürütülen derslerin ve ders yürüten akademisyenlerin belli ölçütler açısından incelenmesidir.

Yöntem: Araştırmada veri toplama yöntemi olarak doküman incelemesi kullanılmış, veri analizi tekniği olarak ise içerik analizi uygulanmıştır.

Bulgular: Elde edilen bulgulara göre derslerin yaklaşık beşte dördünün turizm birimlerindeki akademisyenler tarafından yürütüldüğü belirlenmiş̧ir. Ayrıca erkek akademisyenlerin ve Dr. Öğr. Üyesi unvanındaki akademisyenlerin daha çok ders verdikleri saptanmıştır. Çalışmada akademisyenlerin 41 yayın ortalamasına sahip oldukları ortaya konmuştur. Ayrıca erkek akademisyenlerin yayın ortalamalarının kadınlara kıyasla, turizm birimlerindeki akademisyenlerin yayın ortalamalarının ise diğer birimlerdeki akademisyenlere kıyasla yüksek olduğu sonucuna ulaşı1lmıştır.

Özgünlük/Bilimsel Katkı: Bu araştırma özellikle tezsiz yüksek lisans düzeyindeki rehberlik eğitiminin ve bu eğitimde görev alan akademisyenlerin nicelik ve niteliğinin belirlenmesi üzerine fayda sağlayacaktır.

Anahtar Kelimeler: Turist rehberliği, turist rehberliği eğitimi, akademisyenler, tezsiz yüksek lisans programı, üniversiteler.

Makale Türü: Araştırma makalesi

\begin{abstract}
Purpose and Importance: The aim of this research is to examine the academicians conducting the lectures and the lectures conducted in the non-thesis master's programs in the field of tourist guidance in Turkey in terms of certain criteria.
\end{abstract}

Methodology: In the research, document analysis was used as a data collection method and content analysis was used as a data analysis technique.

Atıf için (for cited); Ak, S. ve Soybalı, H.H. (2021). Turist Rehberliği Tezsiz Yüksek Lisans Eğitimi: Dersler ve Akademisyenler Üzerine Bir Araştırma, Turist Rehberliği Dergisi, 4(2), 119-142. 


\section{IIIII)}

Turist Rehberliği Dergisi (TURED) \& Yıl. 2021, Cilt. 4, Sayı. 2

Journal of Tour Guiding (JOTOG) \& Year. 2021, Volume. 4, Issue. 2

Findings: According to the findings, about four-fifths of the lectures were conducted by academics in tourism departments. Moreover, it was found that male academicians and assistant professors conducted more lectures. In the study, it was revealed that academicians have a publication average of 41 . Furthermore, it has been concluded that the average of publications of male academicians is higher than that of females, and that academicians in tourism departments are higher than academics in other departments.

Originality/Value: This research will be especially useful in determining the non-thesis tourist guidance education and the quantity and quality of the academicians who take part in this education.

Keywords: Tourist guidance, education of tourist guidance, academicians, non-thesis master's program, universities.

Paper Type: Research article

\section{Giriş}

Turist rehberleri, turizm endüstrisinde en önemli aktörler olarak ev sahibi destinasyon ile turistler arasındaki bağı kuran kişilerdir. Turist rehberlerinin verdikleri hizmetlerin temelini başarılı bir şekilde çevresel yorumlama, açıkça tanımlanmış bir kültürel/coğrafi alanda faaliyet gösterme ve uzmanlaşmış dil bilgisi oluşturmaktadır (Ap \& Wong, 2001). Dolayısıyla söz konusu rehberlik hizmetini yerine getirebilmek için turist rehberlerinin aldıkları eğitim süreçlerinde belirli bir düzeyde beceri, bilgi ve yeterlilik kazanmalarının sağlanması oldukça önemlidir. Bu bağlamda dünya genelinde rehberlik mesleğini icra edebilmek adına rehberlik eğitiminin tamamlanmasını gerekli k1lan ülkelerde turist rehberliği eğitimi, her destinasyon veya bölge için ihtiyaçları tanıması ve buna göre eğitim müfredatı oluşturması gereken yerel mevzuata dayalı olarak farklı şekillerde düzenlenmektedir (Lovrentjev, 2015).

Türkiye'de turist rehberi olabilmek ve yetiştirmek için farklı süreçler söz konusudur. Örgün eğitimde ön lisans, lisans, lisansüstü programlarının yürütülmesi ile birlikte yaygın eğitimde sertifika programlarının yer alması, turist rehberliği hizmetinin eğitim açısından değerlendirilmesi gerekliliğini ortaya çıkarmaktadır (Eser, 2020). Nitekim turist rehberlerinin daha aktif ve verimli bir şekilde eğitim öğretimden geçmesi gerekmektedir. Sahip oldukları kritik roller nedeniyle turist rehberlerine hem teorik hem de pratik olarak birçok alanda eğitim verilmesi, ülke turizmi ve imajı için önem taşımaktadır (Doğancılı \& Karaçar, 2018).

Turist rehberliği programlarında görev yapan ve ders yürüten akademisyenlerin çeşitli değişkenler bağlamında değerlendirilmesi, performanslarıyla ilişkili birtakım faktör ve çıktıların ortaya konulması; rehberlik eğitiminin yeterliliğiyle ilgili ipuçları niteliğinde olup kaliteli bir rehberlik eğitimi ve başarılı turist rehberi yetiştirmenin ön koşulu olarak ele alındığından araştırılması gereken ilgi çekici bir konu olarak değerlendirilmektedir. Dolayısıyla akademisyenlerin aldıkları lisans ve lisansüstü eğitimi ile eğitim verdikleri bilim dalının alan bakımından benzerlik durumu, akademik çalışma alanları, kendi alanlarında eğitim verdikleri öğrencilerin niteliklerine doğrudan olumlu fayda sağlayabilecek nitelikler arasında değerlendirilebilir (Baytok vd., 2019).

Turist rehberliği eğitiminin başarılı ve kaliteli bir biçimde yürütülmesinin gereğinden hareketle özellikle turizm alanındaki akademisyenler ve Turist Rehberliği Birliği (TUREB) başta olmak üzere lisansüstü düzeyindeki rehberlik programlarına yönelik görüş ve eleştiriler bağlamında turist rehberlerinin ülke imajı ve turizmi açısından önemi dikkate alındığında ülkemizdeki tezsiz yüksek lisans düzeyinde yürütülen turist rehberliği eğitiminin ayrıca irdelenmesi gereği ortaya çıkmaktadır. Bundan dolayı bu çalışmada 2020-2021 akademik yılında üniversitelerdeki tezsiz yüksek lisans düzeyindeki turist rehberliği programlarında yürütülen dersler esas alınarak ders yürüten akademisyenlerin yapmış oldukları bilimsel 
yayınlar ve yürüttükleri tez danışmanlıklarının turist rehberliği ile ilişkisi gibi özellikler bağlamında değerlendirilmesi amaçlanmaktadır.

\section{Turist Rehberliği Eğitimi}

Türkiye'de turizmin henüz yeni gelişmeye başladığı dönemlerde Kültür ve Turizm Bakanlığı, önemli bir eksikliğin giderilmesi yönünde sorumluluk üstlenerek turist rehberliği kursları düzenlemeye başlamış ve bu kurslara katılıp başarılı bir şekilde mezuniyete hak kazanan kişiler dışında rehberlik hizmeti sunulmasını engelleyen kısıtlamalar getirmiştir (Çolakoğlu vd., 2017). Nitekim 1995 yılına kadar turist rehberleri, yabancı dil bilgisine sahip lise veya üniversite mezunlarının sınav yapılarak alındığı Kültür ve Turizm Bakanlığı tarafindan düzenlenen üç ve altı aylık kurslarla yetiştirilmiştir. Bu kapsamda üç aylık kurslarla bölgesel ve altı aylık kurslarla ise ülkesel rehber eğitimi verilmiştir (Temizkan \& Ergün, 2018). Daha sonraları üniversitelerin ön lisans ve lisans düzeyindeki turist rehberliği programlarında da rehberlik eğitimine başlanmıştır. İlk olarak ön lisans düzeyinde 1990 yılında Ankara Üniversitesi Başkent Meslek Yüksekokulu, lisans düzeyinde ise 1997 yılında Erciyes Üniversitesi Nevşehir Turizm İşletmeciliği ve Otelcilik Yüksekokulu öğrenci alımı gerçekleştirmiştir (Tolga vd., 2015). Son yıllarda lisansüstü düzeyde de turist rehberliği alanında tezli ve tezsiz olarak yüksek lisans programları ile turist rehberliği eğitimi verilmektedir (Eser, 2020). Kısaca başlangıçta yalnızca Kültür ve Turizm Bakanlığı tarafından düzenlenen kurslar aracılığıyla verilen rehberlik eğitimi, günümüzde üniversite eğitim programları kapsamında da yerini almış bulunmaktadır (Ahipaşaoğlu, 2006).

Günümüzde Türkiye'de turist rehberliği eğitimi örgün eğitim ve yaygın eğitim olmak üzere iki farklı biçimde yürütülmektedir. Yaygın eğitim 2012 yılında Turist Rehberliği Meslek Kanunu'nun yürürlüğe girmesiyle birlikte ihtiyaç duyulan bölge ve dilde birlikler tarafından düzenlenen turist rehberliği sertifika programları ile verilmektedir. Örgün eğitim ise ön lisans düzeyinde üniversitelerin meslek yüksekokulları bünyesinde, lisans düzeyinde fakülte veya yüksekokullar bünyesinde ve yüksek lisans düzeyinde de ilgili enstitüler bünyesinde yürütülmektedir (Eker ve Zengin, 2016). Özetle Türkiye'de rehberlik eğitimi; yedi aylık kurslar, iki yıllık ön lisans, dört yıllık lisans ve iki yıllık yüksek lisans olmak üzere dört farklı seviyede verilmektedir. Ayrıca ön lisans programları kendi içlerinde örgün ve uzaktan olarak, lisans programları hem yüksekokul ve fakülte olarak hem de normal öğretim ve ikinci öğretim olarak, yüksek lisans programları ise hem tezli ve normal öğretim hem de tezsiz ve ikinci öğretim olarak ayrılmakta, toplamda dokuz farklı yöntemle rehberlik eğitimi verilmektedir (Çokişler, 2017).

Üniversitelerin meslek yüksekokulları bünyesinde yürütülen ön lisans düzeyindeki turist rehberliği eğitimi, hazırlık programı bulunan programlarda toplam altı yarıyılda tamamlanabilirken hazırlı programı bulunmayan programlarda toplam dört yarıyılda tamamlanabilmektedir (Eker vd., 2019). Söz konusu turist rehberliği ön lisans programları, Kültür ve Turizm Bakanlığı tarafından düzenlenen sertifika programlarına tam anlamıla benzer tek düze bir eğitim programı olarak değerlendirilmese de birçok üniversitede yürütülen ön lisans eğitiminin turist rehberliği sertifika programlarının iki yıla dağıtılmış ve yabancı dil dersleri eklenmiş hali olduğuna yönelik bir yorumda bulunmak mümkündür (Ahipaşaoğlu, 2006). Ayrıca Türkiye'de ön lisans düzeyinde rehberlik eğitimi sunan programların tamamında ilgili programların isimleri "Turist Rehberliği" olarak kabul görmekte ve dolayısıyla rehberlik alanındaki ön lisans programlarının isim bağlamında bir bütünlük arz ettikleri söylenebilmektedir (Albuz vd., 2018). Bu durum rehberlik alanına yönelik örgün eğitimde lisans ve lisansüstü düzeydeki rehberlik programlarıyla karşılaştıılldığında söz konusu bütünlügün sadece ön lisans düzeyinde sağlanabilmiş olması dikkat çekmektedir. 
Türkiye'de 2021 y1lı itibariyle ön lisans düzeyinde turist rehberliği eğitimi toplam 23 üniversitede 27 birim bünyesinde sürdürülmektedir (Yükseköğretim Kurulu Atlas1, 2021).

Türkiye'de 1990'l1 yıllarda meslek yüksekokullarındaki ön lisans düzeyindeki turist rehberliği eğitiminin, özellikle dil eğitimi açısından yeterli olmaması üzerine bazı üniversitelerin Turizm Yüksekokulları bünyesinde dört yıllık turizm rehberliği bölümleri açılarak rehberlik alanında lisans eğitimi ön plana çıkmıştır (Ahipaşaoğlu, 2006). Zaman içerisinde kimi bölümler kapatılsa da yeni açılan bölümler ve artan kontenjanlar dolayısıyla lisans düzeyindeki rehberlik eğitimi yaygınlık kazanmıştır (Eker \& Zengin, 2016). Türkiye'de 2021 itibariyle toplam 36 farklı üniversitede 38 birim bünyesinde lisans düzeyinde turizm rehberliği eğitimi verilmektedir. Türkiye'de lisans düzeyindeki rehberlik eğitiminde yürütülen bölüm isimleri, ön lisans düzeyindeki turist rehberliği programlarında tercih edilen "Turist Rehberliği” yerine "Turizm Rehberliği” olarak yürütülmektedir. Ayrıca günümüzde lisans düzeyinde ağırlıklı olarak "Turizm Rehberliği”" bölümlerinin varlığı dikkat çekse de "Seyahat İşletmeciliği ve Turizm Rehberliği”" bölümlerinde de rehberlik eğitiminin verildiği görülmektedir. Bu bağlamda söz konusu kavram karışıklığının giderilmesi için ortak bir bölüm ismi üzerinden eğitimin sürdürülmesinin yerinde bir hareket olacağını belirtmekte fayda görülmektedir (Albuz vd., 2018). Dolayısıyla 2017 yılındaki 3. Turizm Şurası'nda Turizm Eğitimi, İstihdamı ve Turist Rehberliği Komisyonu'nun (3. Turizm Şûrası, 2017) almış olduğu "Seyahat İşletmeciliği ve Turizm Rehberliği" bölümlerinin ayrılarak "Turizm İşletmeciliği" ve "Turist Rehberliği" bölümleri haline dönüştürülmesine ve bu bölümlerin müfredatlarının da bölüm adı çerçevesinde yeniden düzenlenmesine ilişkin karar da bu yönde değerli bir çözüm önerisi olarak dikkat çekmektedir.

Türkiye'de lisansüstü düzeyindeki rehberlik eğitimi, henüz öğrenci alımı gerçekleşen bir doktora programı olmamasından dolayı tezli ve tezsiz yüksek lisans olmak üzere iki farklı şekilde yürütülmektedir. Türkiye'de turist rehberliği ile ilgili yüksek lisans eğitiminin ilk olarak 2014 yılında Ege Üniversitesi Sosyal Bilimler Enstitüsü bünyesindeki Turizm Rehberliği Anabilim Dalı altında "Rekreasyon ve Turist Rehberliği" tezli yüksek lisans programıyla başladığı görülmektedir (Yenipınar \& Çınar, 2018). Sonrasında rehberlik alanındaki tezli yüksek lisans programları artmıştır. Türkiye'de 2021 itibariyle tamamının devlet üniversitesi olduğu toplam 16 üniversitede rehberlik eğitimi tezli yüksek lisans düzeyinde verilmektedir. Tezli yüksek lisans düzeyindeki rehberlik eğitimi program isimleri bağlamında değerlendirildiğinde program isimlerinin; Turizm Rehberliği, Turist Rehberliği, Seyahat İşletmeciliği ve Turizm Rehberliği, Seyahat İşletmeciliği ve Turist Rehberliği, Ekoturizm Rehberliği, İnanç Turizmi Rehberliği ve Rekreasyon ve Turizm Rehberliği olarak farklılık gösterdiği görülmektedir. Nitekim bu mevcut durum, spesifik alanlarda uzmanlığa yönelen programların çıktısının verilen spesifik eğitimden çok daha geniş olması bakımından (Eser, 2020) tartış1lması gereken bir konu olarak kabul görmektedir.

Türkiye'de turist rehberliği ile ilgili tezsiz yüksek lisans eğitimi 2015-2016 akademik yılında Afyon Kocatepe Üniversitesi Sosyal Bilimler Enstitüsü Turizm Rehberliği Anabilim dalı altında ikinci öğretim olarak Turizm Rehberliği Tezsiz Yüksek Lisans Programı'nın açılmasıyla başlamıştır. Devamında birçok üniversitede tezsiz yüksek lisans programları açılmış ve bu durum, yüksek lisans programlarının gündeme gelme amaçlarının dışında açı1dığını yönünde eleştirileri gündeme getirmiştir (Çokişler, 2017). 2017 yılında düzenlenen 3. Turizm Şurası'nda Turizm Eğitimi, İstihdamı ve Turist Rehberliği Komisyonu tarafından alınan (3. Turizm Şûrası, 2017) "Halen ön lisans ve tezsiz yüksek lisans düzeyinde eğitim veren "Turist Rehberliği” bölümlerinin kapatılması; bunun yerine eğer yoksa aynı üniversitede lisans programlarının açılması ve kadroların bu bölümlere aktarılması, rehberlik eğitiminin lisans ve üzeri programlarda verilmesi, ilgili mevzuatın bu şekilde düzenlenmesi” kararı, 
Turist Rehberliği Dergisi (TURED) \& Yıl. 2021, Cilt. 4, Sayı. 2

Journal of Tour Guiding (JOTOG) \& Year. 2021, Volume. 4, Issue. 2

Türkiye'deki tezsiz yüksek lisans programlarının geleceği açısından önem arz edeceği düşünülmektedir. Ancak kararın aksine bu süreç içerisinde açılan tezsiz yüksek lisans programlarında artışın dikkat çektiği söylenebilir. Bu doğrultuda aşağıdaki Tablo 1 dâhilinde Türkiye'de tezsiz yüksek lisans düzeyinde rehberlik eğitimi veren üniversiteler yer almaktadır.

Tablo 1

Türkiye'de Tezsiz Yüksek Lisans Düzeyinde Rehberlik Eğitimi Veren Üniversiteler

\begin{tabular}{|c|c|c|c|c|}
\hline Üniversite & Kurum & Enstitü & Anabilim Dalı & Program Adı \\
\hline Afyon Kocatepe Üni.* & Devlet & $\begin{array}{l}\text { Sosyal Bilimler } \\
\text { Enstitüsü }\end{array}$ & Turizm Rehberliği & Turizm Rehberliği \\
\hline Akdeniz Üni. & Devlet & $\begin{array}{l}\text { Sosyal Bilimler } \\
\text { Enstitüsü }\end{array}$ & Turizm Rehberliği & Turizm Rehberliği \\
\hline $\begin{array}{l}\text { Ankara Hacı Bayram } \\
\text { Veli Üni. }\end{array}$ & Devlet & $\begin{array}{l}\text { Lisansüstü } \\
\text { Eğitim } \\
\text { Enstitüsü }\end{array}$ & $\begin{array}{l}\text { Seyahat İşletmeciliği ve } \\
\text { Turizm Rehberliği }\end{array}$ & $\begin{array}{l}\text { Seyahat İşletmeciliği ve } \\
\text { Turizm Rehberliği }\end{array}$ \\
\hline Batman Üni. & Devlet & $\begin{array}{l}\text { Sosyal Bilimler } \\
\text { Enstitüsü }\end{array}$ & Turizm Rehberliği & Turizm Rehberliği \\
\hline $\begin{array}{l}\text { Çanakkale Onsekiz } \\
\text { Mart Üni.* }\end{array}$ & Devlet & $\begin{array}{l}\text { Lisansüstü } \\
\text { Eğitim } \\
\text { Enstitüsü }\end{array}$ & $\begin{array}{l}\text { Seyahat İşletmeciliği ve } \\
\text { Turizm Rehberliği }\end{array}$ & Turist Rehberliği \\
\hline $\begin{array}{l}\text { Eskişehir Osmangazi } \\
\text { Üni.* }\end{array}$ & Devlet & $\begin{array}{l}\text { Sosyal Bilimler } \\
\text { Enstitüsü }\end{array}$ & $\begin{array}{l}\text { Seyahat İşletmeciliği ve } \\
\text { Turizm Rehberliği }\end{array}$ & Turist Rehberliği \\
\hline İstanbul Gelişim Üni. & Özel & $\begin{array}{l}\text { Lisansüstü } \\
\text { Eğitim } \\
\text { Enstitüsü }\end{array}$ & Turizm Rehberliği & Turizm Rehberliği \\
\hline $\begin{array}{l}\text { İzmir Katip Çelebi } \\
\text { Üni.* }\end{array}$ & Devlet & $\begin{array}{l}\text { Sosyal Bilimler } \\
\text { Enstitüsü }\end{array}$ & $\begin{array}{l}\text { Seyahat İşletmeciliği ve } \\
\text { Turizm Rehberliği }\end{array}$ & Turist Rehberliği \\
\hline Kapadokya Üni.* & Özel & $\begin{array}{l}\text { Lisansüstü } \\
\text { Eğitim, Öğretim } \\
\text { ve Araştırma } \\
\text { Enstitüsü }\end{array}$ & Turist Rehberliği & Turist Rehberliği \\
\hline Mardin Artuklu Üni.* & Devlet & $\begin{array}{l}\text { Lisansüstü } \\
\text { Eğitim } \\
\text { Enstitüsü }\end{array}$ & Turizm Rehberliği & Turizm Rehberliği \\
\hline $\begin{array}{l}\text { Necmettin Erbakan } \\
\text { Üni. }\end{array}$ & Devlet & $\begin{array}{l}\text { Sosyal Bilimler } \\
\text { Enstitüsü }\end{array}$ & Ekoturizm Rehberliği & Ekoturizm Rehberliği \\
\hline $\begin{array}{l}\text { Recep Tayyip Erdoğan } \\
\text { Üni.* }\end{array}$ & Devlet & $\begin{array}{l}\text { Lisansüstü } \\
\text { Eğitim } \\
\text { Enstitüsü }\end{array}$ & Turizm İşletmeciliği & Turizm Rehberliği \\
\hline Şırnak Üni. & Devlet & $\begin{array}{l}\text { Lisansüstü } \\
\text { Eğitim } \\
\text { Enstitüsü }\end{array}$ & Ekoturizm Rehberliği & Ekoturizm Rehberliği \\
\hline
\end{tabular}

*: 2020-2021 Akademik Yılı Genelinde Aktif Turist/Turizm Rehberliği Bölümleri

Kaynak: Üniversitelerin birim web siteleri incelenerek derlenmiştir.

Tablo 1 dâhilinde Türkiye'de tezsiz yüksek lisans düzeyinde rehberlik eğitimi kapsamında altı adet turizm rehberliği, dört adet turist rehberliği, iki adet ekoturizm rehberliği ve bir adet seyahat işletmeciliği ve turizm rehberliği olmak üzere toplam 13 adet program bulunduğu görülmektedir. Nitekim seyahat işletmeciliği kapsamında işletme ve rehberlik eğitimini birleştiren ya da spesifik bir alana yönelerek rehberlik eğitimini sürdüren programların varlığ 1 dikkat çekse de 10 üniversitede turizm/turist rehberliği programı bulunmaktadır. Ayrıca ilgili üniversiteler arasındaki iki üniversitede (Akdeniz Üniversitesi ve Batman Üniversitesi) 2020-2021 akademik y1lında öğrenci alımı gerçekleşmemiş, İstanbul 
Turist Rehberliği Dergisi (TURED) \& Yıl. 2021, Cilt. 4, Sayı. 2

Journal of Tour Guiding (JOTOG) \& Year. 2021, Volume. 4, Issue. 2

Gelişim Üniversitesi'nde ise program 2020-2021 akademik y1lının bahar döneminde açılmıştır.

Tablo 1'de 2020-2021 akademik y1l genelinde alt1 devlet üniversitesi (Afyon Kocatepe Üniversitesi, Çanakkale Onsekiz Mart Üniversitesi, Eskişehir Osmangazi Üniversitesi, İzmir Katip Çelebi Üniversitesi, Mardin Artuklu Üniversitesi, Recep Tayyip Erdoğan Üniversitesi) ve bir özel üniversite (Kapadokya Üniversitesi) olmak üzere toplam yedi üniversitede turist/turizm rehberliği tezsiz yüksek lisans programının aktif olarak sürdürüldüğü görülmektedir. Bu araştırmanın kapsamındaki aktif olarak eğitimin sürdügü üniversitelerde ilgili programın isimlendirilmesinde "turist rehberliği" ve "turizm rehberliği" olarak ikiye bölünme söz konusu olduğu, dört programın "turist rehberliği", üç programın ise "turizm rehberliği" olarak isimlendirildiği görülmektedir. Söz konusu programların üçü "Sosyal Bilimler Enstitüsü”, üçü "Lisansüstü Eğitim Enstitüsü”, biri de "Lisansüstü Eğitim, Öğretim ve Araştırma Enstitüsü" bünyesinde yer almaktadır. Ayrıca turist/turizm rehberliği programlarının üçünün "Turist/Turizm Rehberliği Anabilim Dalı" altında açıldığı görülmekle birlikte üçünün "Seyahat İşletmeciliği ve Turizm Rehberliği Anabilim Dalı" altında, birinin de "Turizm İşletmeciliği Anabilim Dalı" altında açıldığı görülmektedir.

\section{Tablo 2}

Türkiye'de Rehberlik Eğitiminin İncelenmesine İlişkin Bazı Çalışmalar

\begin{tabular}{|c|c|}
\hline Araştırma & Bulgu ve Sonuçlar \\
\hline $\begin{array}{c}\text { Yenipınar ve } \\
\text { Zorkirişci (2013) }\end{array}$ & $\begin{array}{l}\text { Türkiye'de lisans düzeyindeki rehberlik bölümlerinin ders programları ile Avrupa Birliği } \\
\text { ülkelerindeki rehberlik programlarının incelendiği bu araştırma sonucunda Türkiye'de yeni } \\
\text { açılacak turist rehberliği lisans bölümlerinin tercih edebileceği yeni ve güncel ders konuları } \\
\text { belirlenerek öneriler paylaşılmıştır. }\end{array}$ \\
\hline $\begin{array}{c}\text { Güven ve } \\
\text { Ceylan (2014) }\end{array}$ & $\begin{array}{l}\text { Rehberlik eğitimi veren yükseköğretim kurumları arasında müfredat birliği olmadığı, } \\
\text { yönetmelik tarafından alınması zorunlu derslerin bazılarının üniversitelerin müfredatlarında } \\
\text { bulunmadığı veya seçmeli ders olarak yer aldığ } 1 \text {, ders isimlerinin de yönetmelikte belirlenen } \\
\text { ders isimlerinden farklı olduğu sonucuna varılmıştır. }\end{array}$ \\
\hline $\begin{array}{l}\text { Eker ve Zengin } \\
\quad(2016)\end{array}$ & $\begin{array}{l}\text { Araştırma kapsamındaki turist rehberlerinin yetiştirilmesinde eğitim kurumlarının önemli } \\
\text { bir yerinin olmasıyla birlikte mesleği icra edebilme noktasında teorik eğitimin yetersiz } \\
\text { kaldığl, uygulamalar ile rehberlik eğitiminin desteklenmesi gerektiği sonucuna ulaşılmıştır. }\end{array}$ \\
\hline $\begin{array}{l}\text { Bayram vd. } \\
\text { (2017) }\end{array}$ & $\begin{array}{l}\text { Çalışmada örgün eğitimde ekoturizm kavramının farklı isimlendirmelerle de olsa mevcut } \\
\text { olduğu ancak turizm rehberliği ögrencilerinin çevresel etik ve çevreci tutum gibi hassas } \\
\text { konuları içeren daha geniş bir bakış açısına sahip olmaları gerektiği sonucuna varılmıştır. }\end{array}$ \\
\hline Çokişler (2017) & $\begin{array}{l}\text { Rehberlik eğitiminin parçalanmış yapısında; bakanlık, TUREB, YÖK ve TÜRSAB gibi } \\
\text { paydaşların arasındaki çekişmelerin payı olduğu üzerinde durularak rehberlik eğitiminde } \\
\text { çözümün tezli yüksek lisans eğitimi olduğuna ilişkin gerekçeler sunulmuştur. }\end{array}$ \\
\hline Albuz vd. (2018) & $\begin{array}{l}\text { Araştırmacılar, Türkiye'de ön lisans ve lisans düzeyinde turist rehberliği eğitimi veren } \\
\text { üniversiteleri, program sayılarını, kontenjanlarını, kontenjan doluluk oranlarını, unvan ve } \\
\text { ruhsatname sahibi olup olmama durumlarına göre öğretim üyesi ve öğretim elemanı } \\
\text { sayılarını derleyerek, ön lisans ve lisans düzeyindeki rehberlik eğitimine ait 2017-2018 } \\
\text { akademik yılı verilerinin ortaya koyup bir durum tespiti gerçekleştirmişlerdir. }\end{array}$ \\
\hline $\begin{array}{c}\text { Başoda ve Aylan } \\
\text { (2018) }\end{array}$ & $\begin{array}{l}\text { Araştırma sonucunda rehberlik lisans bölümlerinin Türkiye'deki üniversitelerin dörtte } \\
\text { birinde mevcut olduğu görülmektedir. Bununla birlikte 2017-2018 akademik y1lında } \\
\text { rehberlik lisans bölümlerinin bulunduğu üniversitelerin çoğunluğu turizm fakülteleridir. } \\
\text { Coğrafik olarak ise rehberlik lisans programlarında aktif eğitimin sürdürüldüğü } \\
\text { üniversitelerin yoğun olduğu bölgeler, Ege ve İç Anadolu olarak saptanmıştır. }\end{array}$ \\
\hline $\begin{array}{c}\text { Çakmak ve } \\
\text { Dinçer (2018) }\end{array}$ & $\begin{array}{l}\text { Yapılan araştırma sonucunda programların Türk kültürü, mimarisi ve mitolojik inanç } \\
\text { temelleri gibi kavramlar üzerine yoğunlaştıkları belirlenmiştir. Ayrıca incelenen ders } \\
\text { içeriklerinde Türklük kavramı ve köklerinin ağırlıklı olarak mitolojik hikayeler } \\
\text { çerçevesinde işlendiği ve ayrıca büyük Türk devletlerinin dünya ve Türk tarihi açısından } \\
\text { önemine yeterince yer verilmediği tespit edilerek çeşitli önerilerde bulunulmuştur. }\end{array}$ \\
\hline
\end{tabular}


Turist Rehberliği Dergisi (TURED) \& Yıl. 2021, Cilt. 4, Sayı. 2

Journal of Tour Guiding (JOTOG) \& Year. 2021, Volume. 4, Issue. 2

Tablo 2

Türkiye'de Rehberlik Eğitiminin İncelenmesine İlişkin Bazı Çalı̧̧malar (Devamı)

\begin{tabular}{|c|c|}
\hline Araştırma & Bulgu ve Sonuçlar \\
\hline $\begin{array}{l}\text { İşçeli ve Kilıç } \\
\text { (2018) }\end{array}$ & $\begin{array}{l}\text { Araştırma sonucunda Turist Rehberliği Meslek Yönetmeliği doğrultusunda sertifika } \\
\text { programlarında okutulması zorunlu olan bazı derslerin bazı üniversitelerde seçmeli ders } \\
\text { olarak okutulduğu görülmüştür. Bununla birlikte, üniversiteler arasında müfredat açısından } \\
\text { da birtakım farklılıklar olduğu tespit edilmiş, ders isimlerinin ilgili bölümlerde değişebildiği } \\
\text { ve derslerin farklı sınıf ve dönemlerde açılabildiği saptanmıştır. }\end{array}$ \\
\hline Kürkçü (2018) & $\begin{array}{l}\text { Çalışmada turist rehberliği bölümlerinin turizm fakültelerinden ayrılarak sosyal ve beşeri } \\
\text { bilimler ya da insan ve toplum bilimleri fakülteleri bünyesine dâhil edilmelerinin rehberlik } \\
\text { mesleğinin ve ülke turizminin geleceği adına daha faydalı olacağı gündeme getirilmiştir. }\end{array}$ \\
\hline $\begin{array}{l}\text { Yenipınar ve } \\
\text { Çınar (2018) }\end{array}$ & $\begin{array}{l}\text { Çalışmada Türkiye'de faaliyet gösteren } 13 \text { Turist Rehberi Odası yönetim kurulu üyesi ile } \\
\text { yüksek lisans ve lisans eğitimi yürütülen turizm rehberliği bölümü akademisyenlerinin } \\
\text { görüşlerine başvurulmuştur. Çalışma sonucunda turist rehberliği yüksek lisans eğitiminin } \\
\text { olumlu ve olumsuz yönleri ile ilgili tespit edilen bulgular ve turist rehberliği yüksek lisans } \\
\text { eğitiminin geliştirilmesi ile ilgili öneriler üzerinde durulmuştur. }\end{array}$ \\
\hline $\begin{array}{l}\text { Temizkan ve } \\
\text { Ergün (2018) }\end{array}$ & $\begin{array}{l}\text { Türkiye'de turist rehberliği öğretiminin değerlendirilmesi amacıyla Türkiye'de turist } \\
\text { rehberliği öğretimi veren kurumları ve kontenjanları incelenmiştir. Araştırmada farklı } \\
\text { şekillerde verilen rehberlik eğitimi de dikkate alınarak açılan kontenjanların yüksek olduğu } \\
\text { gözlemlenmiş ve bir planlama yapılması gerektiği sonucu üzerinde durulmuştur. }\end{array}$ \\
\hline $\begin{array}{c}\text { Sezerel ve } \\
\text { Özoğul (2019) }\end{array}$ & $\begin{array}{l}\text { Uzman mantosu yaklaşımının turist rehberliği eğitiminde uygulanabilirliği üzerinde } \\
\text { yoğunlaşıldığ bu araştırmada rehberlik lisans öğrencilerinin mesleki hayatlarıyla } \\
\text { bağdaşıracakları konuları uzman mantosu yaklaşımı ile ele almalarının etkili olduğu } \\
\text { sonucuna ulaşılmıştır. }\end{array}$ \\
\hline $\begin{array}{l}\text { Yenipınar ve } \\
\text { Kardaş (2019) }\end{array}$ & $\begin{array}{l}\text { Araştırma neticesinde lisans programlarındaki temel teorik derslerin beklentileri karşılar } \\
\text { nitelikte olduğu ancak turizmde güncel konular, yabancı dil eğitimi, bölgesel temalı dersler } \\
\text { ve uygulamalı derslerin sınırlı kaldığı belirlenerek birtakım öneriler geliştirilmiştir. }\end{array}$ \\
\hline Eser & $\begin{array}{l}\text { Sonuç olarak üniversitelerin turizm rehberliği yüksek lisans programlarındaki benzerlik ve } \\
\text { farklılıkların ortaya konulması üzerine yoğunlaşılan bu çalışmada üniversitelerin turist } \\
\text { rehberliği lisansüstü programlarına kabul koşullarında, program adlarında, zorunlu ve } \\
\text { seçmeli dersler arasında farklılıklar olduğu saptanmıştır. }\end{array}$ \\
\hline $\begin{array}{l}\text { Temizkan ve } \\
\text { Ergün }(2021)\end{array}$ & $\begin{array}{l}\text { Araştırmada "müfredat ve öğretim kalitesi”, "akademik personel kalitesi”, "yönetim ve } \\
\text { destek hizmetleri", "öğretim ortamı" ve "öğretim sonucu kazanımlar" boyutlarında toplanan } \\
47 \text { maddeli bir ölçek oluşturulmuş ve sonuçlar turist rehberliği öğretimi kalitesi ölçeğinin } \\
\text { geçerli ve güvenilir bir ölçme aracı olduğunu göstermiştir. }\end{array}$ \\
\hline $\begin{array}{l}\text { Temizkan ve } \\
\text { Timur }(2021\end{array}$ & $\begin{array}{l}\text { Araştırma sonuçları ilgili değişkenler arasında anlamlı ve pozitif yönlü ilişkiler olduğunu } \\
\text { ortaya koyarak turist rehberliği eğitiminin lisans düzeyinde verilmesinin gerektiğine ve } \\
\text { tezsiz yüksek lisans modelinin nadir dillerde rehber sorununun çözülmesinde } \\
\text { kullanılmasına işaret etmektedir. }\end{array}$ \\
\hline Topsakal (2021 & $\begin{array}{l}\text { Yapılan çalışma sonucunda sertifika programlarında verilen derslerin tezli ve tezsiz yüksek } \\
\text { lisans müfredatlarında kısmen yer aldığı; bu derslerin çoğunun seçmeli ders olarak verildiği; } \\
\text { mitoloji, ikonografi, müzecilik, sanat tarihi ve arkeoloji derslerinin ise birleştirilip tek ders } \\
\text { adı altında verildiği ve bir üniversite haricinde herhangi bir yabancı dil dersi verilmediği } \\
\text { ortaya çıkarılmıştır. }\end{array}$ \\
\hline
\end{tabular}

Alan yazında turist rehberliği eğitimini konu edinen birçok çalışmaya rastlamak mümkündür. $\mathrm{Bu}$ çalışmaları, turist rehberliği eğitiminin incelenmesine ilişkin yapılan çalışmalar (Albuz vd., 2018; Başoda \& Aylan, 2018; Bayram vd., 2017; Çakmak \& Dinçer, 2018; Çokişler, 2017; Eker \& Zengin, 2016; Eser, 2020; Güven \& Ceylan, 2014; İşçeli \& K1lıç, 2018; Kürkçü, 2018; Sezerel \& Özoğul, 2019; Temizkan \& Timur, 2021; Temizkan \& Ergün, 2018, 2021; Topsakal, 2021; Yenipınar \& Çınar, 2018; Yenipınar \& Zorkirişci, 2013; Yenipinar \& Kardaş, 2019) ve turist rehberliği eğitimindeki akademisyenlere ilişkin yapılan çalışmalar (Baytok vd., 2019; Kabakulak \& Boyraz, 2020; Boyraz \& Kabakulak, 2020; Doğancılı \& Karaçar, 2018; Aylan \& Başoda, 2018; Demirbulat vd., 2018) şeklinde Tablo 2 ve Tablo 3'te incelemek mümkündür. İki ayrı tablo dâhilinde sınıflandırmak çalışmaları sonuçlar bağlamında incelerken bütünlük sağlanması adına faydalı olacaktır. 
Turist Rehberliği Dergisi (TURED) \& Yıl. 2021, Cilt. 4, Sayı. 2

Journal of Tour Guiding (JOTOG) \& Year. 2021, Volume. 4, Issue. 2

Tablo 3

Türkiye'de Rehberlik Eğitimindeki Akademisyenlere İlişkin Bazı Çalışmalar

\begin{tabular}{|c|c|}
\hline Araştırma & Bulgu ve Sonuçlar \\
\hline $\begin{array}{l}\text { Aylan ve Başoda } \\
\text { (2018) }\end{array}$ & $\begin{array}{l}\text { Çalışmada öğrenci kabulü için gereken asgari sayıda öğretim üyesinin bulunması } \\
\text { zorunluğu, rehberlik lisans bölümlerinde Dr. Öğr. Üyesi unvanlı akademisyenlerin } \\
\text { istihdamını arttırmasıyla ilişkilendirilmiştir. Bununla birlikte çalışmada rehberlik } \\
\text { bölümlerinde yer alan akademik personelin sosyal bilimlerden teknik bilimlere kadar çok } \\
\text { farklı alanlardan mezun oldukları belirlenmiş, dolayısıyla rehber kökenli akademisyen } \\
\text { sayısının ve özellikle de bölüm başkanı sayısının az kaldığı saptanmıştır. }\end{array}$ \\
\hline $\begin{array}{l}\text { Demirbulat vd. } \\
\text { (2018) }\end{array}$ & $\begin{array}{l}\text { Çalışmada akademisyenlerin lisans, yüksek lisans ve doktora mezuniyetleri } \\
\text { incelendiğinde; büyük çoğunluğunun turizm ile ilgili herhangi bir yükseköğretim } \\
\text { programından/bölümünden mezun oldukları tespit edilmiş; rehber olan akademisyenlerin } \\
\text { oranının \% } 28,5 \text { olduğu sonucuna ulaş1lmıştır. Araştırmada; işletme, arkeoloji, yabanc1 } \\
\text { diller eğitimi ve sanat tarihi lisans bölümlerinden mezun olan akademisyenlerin de turizm } \\
\text { rehberliği bölümlerinde önemli oranlarda görev yaptıkları tespit edilmiştir. }\end{array}$ \\
\hline $\begin{array}{c}\text { Doğancilı ve } \\
\text { Karaçar (2018) }\end{array}$ & $\begin{array}{l}\text { Araştırmada rehberlik üzerine yapılan çalışmaların genelde tebliğlerde yoğunlaştı̆̆ ve } \\
\text { yazar sayısının bu çalışmalarda daha fazla olduğu sonucuna ulaşıllmıştır. Son olarak yayın } \\
\text { sayısına bakıldığında en çok yayının Dr. Öğr. Üyesi kadrosundaki akademisyenler } \\
\text { tarafından üretildiği ortaya konmuştur. Çalışmada akademisyenlerin bölümlerine } \\
\text { bakıldığında farklı bölümlerden de mezun olan kişilerin bölüme geçirilmeleri göz önüne } \\
\text { alınarak kadroya alınan kişilere bölüm kapsamında sınırlamalar getirilmesi önerilmiştir. }\end{array}$ \\
\hline Baytok vd. (2019) & $\begin{array}{l}\text { Araştırma sonucunda akademisyenlerin } \% 57,2 \text { 'sinin turizm alanında farklı bölümlerde, } \\
\% 25 \text {, inin ise turizm rehberliği bölümünde lisans eğitimini tamamladıkları ve sadece } \\
\% 20 \text { 'sinin çalı̧̧ma kartına sahip rehberler oldukları saptanmıştır. İdari görevi bulunan } \\
\text { akademisyenlerin ise daha çok unvan dikkat alınarak uzmanlı alanı turizm rehberliği } \\
\text { dışında olan akademik personellerden seçildikleri sonucuna ulaşılmıştır. }\end{array}$ \\
\hline $\begin{array}{c}\text { Boyraz ve } \\
\text { Kabakulak (2020) }\end{array}$ & $\begin{array}{l}\text { Araştırma sonuçlarında rehberlik bölümlerinde toplam } 290 \text { akademisyenin çalıştığı ve } \\
\text { akademisyenlerin en çok bildiri ve makale olmak üzere yayın dilinin çoğunlukla Türkçe } \\
\text { olduğu toplam } 6601 \text { yayın ürettikleri tespit edilmiştir. }\end{array}$ \\
\hline $\begin{array}{l}\text { Kabakulak ve } \\
\text { Boyraz (2020) }\end{array}$ & $\begin{array}{l}\text { Turist rehberi olan akademisyenlerin } 626 \text { bildiri, } 488 \text { makale, } 279 \text { kitap bölümü ve } 22 \\
\text { kitap olmak üzere toplam } 1415 \text { yayın ürettikleri ve yayın dili açısından ağırlıkla Türkçe } \\
\text { yayınların öne çıktığ1 sonucuna varılmıştır. }\end{array}$ \\
\hline
\end{tabular}

\section{Yöntem}

$\mathrm{Bu}$ araştırmanın amacı, Türkiye'deki turist/turizm rehberliği tezsiz yüksek lisans programlarında yürütülen derslerin ve ders yürüten akademisyenlerin belli ölçütler açısından incelenmesidir. $\mathrm{Bu}$ amaç doğrultusunda ilgili akademisyenlerin birtakım demografik ve bireysel özellikleri (cinsiyet, unvan, çalışılan kurum türü, kadrosunun yer aldığı birim-bölümprogram/anabilim dalı, idari görev durumu, mezun olduğu lisans-yüksek lisans-doktora eğitim alanı) ele alınmıştır. Ayrıca akademisyenlerin yapmış oldukları bilimsel yayınlar (makale, kitap, kitap bölümü, bildiri) ve yürüttükleri tez danışmanlıkları, turist rehberliği ile ilişkisi bağlamında değerlendirilmiştir. Araştırma, Türkiye'deki tezsiz yüksek lisans düzeyindeki turist rehberliği eğitiminin mevcut durumunu açılan dersler ve ders yürüten akademisyenler özelinde ortaya koyması açısından önem arz etmektedir. Bu yönüyle araştırma, Türkiye'deki tezsiz yüksek lisans düzeyindeki turist rehberliği eğitimine yönelik öneriler getirilmesi bakımından da önemlidir.

Araştırmada uygulama aşamasında veri toplama yöntemi olarak doküman incelemesi tekniğinden yararlanılmıştır. Bu bağlamda araştırma kapsamındaki turist rehberliği alanında tezsiz yüksek lisans düzeyinde açılan dersler ve ders veren akademisyenlere ilişkin veriler, 1014 Mayıs 2021 zaman diliminde Yükseköğretim Kurulu Akademik arama adresinden (https://akademik.yok.gov.tr/AkademikArama) ve üniversitelerin birim web sayfalarından yararlanılarak elde edilmiştir. 
$\mathrm{Bu}$ araştırmanın evrenini, Türkiye'deki tezsiz yüksek lisans düzeyinde turist/turizm rehberliği eğitimi veren üniversitelerde ilgili programda aktif olarak açılan dersler ve ders vermekte olan akademisyenler oluşturmaktadır. Bu bağlamda çalışma kapsamında öncelikle Türkiye'deki tezsiz yüksek lisans düzeyindeki turist rehberliği programları tespit edilmiş; altıs1 devlet üniversitesi, biri özel üniversite olmak üzere toplam yedi üniversitedeki tezsiz turist/turizm rehberliği programında 2020-2021 akademik y1lında eğitimin sürdürüldüğü görülmüştür. Dolayısıyla bu araştırmada bir örneklem tekniği uygulanmamış, evrenin tamamına ulaşılması amaçlanmıştır. Ayrıca akademisyenlerin turist/turizm rehberliği programlarında girmiş oldukları dersler bağlamında da değerlendirme yapılacağından dolayı ders gruplarında bütünlük sağlamak adına bu çalışmaya Seyahat İşletmeciliği ve Turizm Rehberliği, Ekoturizm Rehberliği, Rekreasyon ve Turist Rehberliği tezsiz yüksek lisans programları kapsamında turist rehberliği eğitimi veren üniversiteler dâhil edilmemiştir. $\mathrm{Bu}$ doğrultuda 2020-2021 akademik y1lında güz ve bahar dönemlerinde ilgili üniversitelerin ilgili birimlerinde (enstitü ve fakülte web sayfaları) yayımlanan güz ve bahar dönemlerine ilişkin açılan dersleri kapsayan ders programları incelenerek araştırmada veri analizi tekniği olarak içerik analizi uygulanmıştır.

\section{Bulgular}

Araştırmanın bu bölümünde öncelikle araştırma dâhilinde yer alan turist/turizm rehberliği tezsiz programı bulunan üniversitelere ve derslere ilişkin bulgulara verilmektedir. Bu noktada üniversitelere ilişkin tanıtıcı bilgiler ve açılan dersler incelenmektedir. Daha sonra söz konusu üniversitelerde turist/turizm rehberliği tezsiz yüksek lisans düzeyinde ders veren akademisyenler, bazı demografik ve bireysel özellikleri bağlamında ele alınmıştır. Ayrıca akademisyenlerin yapmış oldukları bilimsel yayınların (makale, kitap, kitap bölümü, bildiri) ve yürüttükleri tez danışmanlıklarının, konu ve alan çerçevesinde turist rehberliği ile ilişkisi ortaya konulmaktadır.

\subsection{Araştırma Kapsamındaki Üniversite ve Yürütülen Derslere İlişkin Bulgular}

Türkiye'de 2020-2021 akademik yılında aktif olarak tezsiz yüksek lisans düzeyinde turist/turizm rehberliği programı bulunan üniversitelerde 2020-2021 akademik yılının güz ve bahar dönemlerinde açılan derslere ilişkin bilgiler aşağıdaki Tablo 4 'te sunulmuştur. Söz konusu programlarda açılan dersler, bazı üniversitelerdeki eğitimin üç dönem sürdürüldüğü ve ayrıca bahar dönemlerinde de öğrenci alımları gerçekleştirildiği dikkate alındığında güz ve bahar dönemlerinde öğrencilerin dönemlerine bakılmaksızın açılan derslerin tamamını kapsamaktadır. Son olarak bu çalışma ve Tablo 4 'te danışmanlık ve bitirme projeleriyle ilgili derslerin incelemeye alınmadığını söylemekte fayda görülmektedir. Tablo 4 incelendiğinde Afyon Kocatepe Üniversitesi'nde 15, Çanakkale Onsekiz Mart Üniversitesi'nde 16, Eskişehir Osmangazi Üniversitesi'nde 17, İzmir Katip Çelebi Üniversitesi'nde 15, Kapadokya Üniversitesi'nde 11, Mardin Artuklu Üniversitesi'nde 23, Recep Tayyip Erdoğan Üniversitesi'nde 11 ders olmak üzere toplam 108 dersin açıldığı (danıșmanlık ve bitirme projeleriyle ilgili dersler hariç) görülmektedir. Söz konusu dersler konu, kapsam ve alan itibariyle değerlendirildiğinde ilgili üniversitelerde toplam 39 farklı ders bulunmaktadır. Ayrıca üniversitelerin bu dersleri çeşitlendirerek farklı ders isimleriyle de açtıkları görülmektedir.

Tablo 4'te belirtilen toplam 39 ders kapsamındaki beş dersin (Tur Organizasyonu ve Yönetimi, Sosyal Sorumluluk ve Meslek Etiği, Turizm Ekonomisi, Turizm Pazarlamas1, Turist Davranışları) en az iki üniversitede bulunduğu; 18 dersin (Genel Turizm Bilgisi ve Turizm Mevzuatı, Turizm Rehberliği, Türkiye'nin Turizm Coğrafyası, Türkiye Flora Faunası ve Doğa Tarihi, Arkeoloji ve Müzecilik, Mitoloji, Anadolu Medeniyetleri Tarihi, İletişim Becerileri, 
Turist Rehberliği Dergisi (TURED) \& Yı1. 2021, Cilt. 4, Sayı. 2

Journal of Tour Guiding (JOTOG) \& Year. 2021, Volume. 4, Issue. 2

Dinler Tarihi, Sanat Tarihi ve İkonografi, Türk Halk Bilimi ve Geleneksel Türk El Sanatları, Genel Türk Tarihi ve Kültürü, Bilimsel Araştırma Yöntemleri ve Yayın Etiği, Genel Sağlık Bilgisi ve İlk Yardım, Turizm Sosyolojisi, Rehberlik ve Gastronomi, Seyahat Acentacılığı ve Tur Operatörlüğü, Özel İlgi Turizmi) en az üç üniversitede açılan derslerle karşılık bularak ilişkilendirildiği görülmektedir. Dolayısıyla söz konusu derslerin, Turist Rehberliği Meslek Yönetmeliği (2014) kapsamında belirtilen sertifika programlarında okutulması zorunlu derslerle (Genel Turizm Bilgisi ve Turizm Mevzuatı, Meslek Etiği Ve Meslek Dersi, Türkiye'nin Tarihi ve Turizm Coğrafyası, Genel Türk Tarihi ve Kültürü, Türk Dili ve Edebiyat1, Arkeoloji, Mitoloji, Sanat Tarihi, İkonografi, Dinler Tarihi, Genel Sağlık Bilgisi, İlk Yardım, Sağlık Turizmi, Turist Sağlı̆̆ı, İletișim Becerileri, Anadolu Medeniyetleri Tarihi, Türk Halk Bilimi ve Geleneksel Türk El Sanatları, Türkiye'nin Flora ve Faunası, Doğa Tarihi, Turizm Sosyolojisi, Müzecilik) de yüksek oranda bağdaştığı söylenebilir.

Tablo 4

Turist/Turizm Rehberliği Tezsiz Yüksek Lisans Programlarında Açılan Dersler (2020-2021)

\begin{tabular}{|c|c|c|c|c|c|c|c|c|}
\hline DERSLER & $\begin{array}{c}\text { Afyon } \\
\text { Kocatepe } \\
\text { Ü. }\end{array}$ & $\begin{array}{l}\text { Çanakkale } \\
\text { Onsekiz } \\
\text { Mart Ü. }\end{array}$ & $\begin{array}{l}\text { Eskișehir } \\
\text { Osmangazi } \\
\text { Ü. }\end{array}$ & $\begin{array}{c}\text { İzmir } \\
\text { Katip } \\
\text { Çelebi Ü. }\end{array}$ & $\begin{array}{c}\text { Kapadokya } \\
\text { Ü. }\end{array}$ & $\begin{array}{c}\text { Mardin } \\
\text { Artuklu Ü. }\end{array}$ & $\begin{array}{c}\text { Recep } \\
\text { Tayyip } \\
\text { Erdoğan } \\
\text { Ü. }\end{array}$ & $\stackrel{\dot{a}}{\stackrel{9}{\theta}}$ \\
\hline $\begin{array}{l}\text { Genel Turizm } \\
\text { Bilgisi ve Turizm } \\
\text { Mevzuatı }\end{array}$ & + & & + & $\begin{array}{c}\text { Genel } \\
\text { Turizm } \\
\text { Bilgisi ve } \\
\text { Mevzuatı }\end{array}$ & & $\begin{array}{c}\text { Genel Turizm } \\
\text { ve Turizm } \\
\text { Mevzuatı }\end{array}$ & + & 5 \\
\hline Turizm Rehberliği & + & + & $\begin{array}{c}\text { Turizmde } \\
\text { Rehberlik } \\
\text { Mesleği ve } \\
\text { Meslek Etiği }\end{array}$ & $\begin{array}{c}\text { Turizm } \\
\text { Rehberlik } \\
\text { Mesleği ve } \\
\text { Meslek } \\
\text { Etiği }\end{array}$ & & $\begin{array}{c}\text { Turizm } \\
\text { Rehberliği ve } \\
\text { Meslek Etiği }\end{array}$ & + & 6 \\
\hline $\begin{array}{l}\text { Türkiye'nin Turizm } \\
\text { Coğrafyası }\end{array}$ & + & $\begin{array}{c}\text { Türkiye } \\
\text { Coğrafyası ve } \\
\text { Tur } \\
\text { Güzergahları }\end{array}$ & $\begin{array}{l}\text { Türkiye } \\
\text { Turizm } \\
\text { Coğrafyası, }\end{array}$ & $\begin{array}{l}\text { Türkiye'nin } \\
\text { Tarihi ve } \\
\text { Turizm } \\
\text { Coğrafyası }\end{array}$ & & + & + & 6 \\
\hline $\begin{array}{l}\text { Türkiye Flora } \\
\text { Faunas1 ve Doğa } \\
\text { Tarihi }\end{array}$ & + & & $\begin{array}{l}\text { Flora ve } \\
\text { Faunası }\end{array}$ & + & & + & & $3(4)$ \\
\hline $\begin{array}{l}\text { Arkeoloji ve } \\
\text { Müzecilik }\end{array}$ & + & Arkeoloji & $\begin{array}{c}\text { Anadolu } \\
\text { Arkeolojisi } \\
\text { ve Müzecilik }\end{array}$ & + & & + & & 5 \\
\hline Mitoloji & + & + & Mitoloji ve & $\begin{array}{l}\text { Mitoloji ve } \\
\text { İkonografi }\end{array}$ & + & $\begin{array}{l}\text { Mitoloji ve } \\
\text { İkonografi }\end{array}$ & + & 7 \\
\hline $\begin{array}{l}\text { Anadolu } \\
\text { Medeniyetleri } \\
\text { Tarihi }\end{array}$ & + & $\begin{array}{c}\text { Anadolu } \\
\text { Medeniyetleri }\end{array}$ & $\begin{array}{c}\text { Anadolu } \\
\text { Medeniyetleri } \\
\text { Tarihi }\end{array}$ & + & & $\begin{array}{c}\text { Anadolu } \\
\text { Medeniyetleri }\end{array}$ & + & $5(6)$ \\
\hline İletişim Becerileri & $\begin{array}{l}\text { Genel ve } \\
\text { Mesleki } \\
\text { İletişim } \\
\text { Becerileri }\end{array}$ & + & $\begin{array}{l}\text { İletişim } \\
\text { Becerileri, } \\
\text { Görgü ve } \\
\text { Protokol } \\
\text { Kuralları }\end{array}$ & + & & + & & 5 \\
\hline Dinler Tarihi & & + & + & + & + & + & & 5 \\
\hline
\end{tabular}


Turist Rehberliği Dergisi (TURED) \& Yıl. 2021, Cilt. 4, Sayı. 2

Journal of Tour Guiding (JOTOG) \& Year. 2021, Volume. 4, Issue. 2

Tablo 4

Turist/Turizm Rehberliği Tezsiz Yüksek Lisans Programlarında Açılan Dersler (2020-2021)

(Devami)

\begin{tabular}{|c|c|c|c|c|c|c|c|c|}
\hline DERSLER & $\begin{array}{c}\text { Afyon } \\
\text { Kocatepe } \\
\text { Ü. }\end{array}$ & $\begin{array}{l}\text { Çanakkale } \\
\text { Onsekiz } \\
\text { Mart Ü. }\end{array}$ & $\begin{array}{l}\text { Eskişehir } \\
\text { Osmangazi } \\
\text { Ü. }\end{array}$ & $\begin{array}{c}\text { İzmir } \\
\text { Katip } \\
\text { Çelebi Ü. }\end{array}$ & $\begin{array}{c}\text { Kapadokya } \\
\text { Ü. }\end{array}$ & $\begin{array}{l}\text { Mardin } \\
\text { Artuklu } \\
\text { Ü. }\end{array}$ & $\begin{array}{l}\text { Recep } \\
\text { Tayyip } \\
\text { Erdoğan } \\
\text { Ü. }\end{array}$ & $\dot{\theta}$ \\
\hline $\begin{array}{l}\text { Sanat Tarihi ve } \\
\text { İkonografi }\end{array}$ & + & + & + & $\begin{array}{l}\text { Sanat } \\
\text { Tarihi }\end{array}$ & $\begin{array}{c}\text { Türk ve } \\
\text { Dünya } \\
\text { Sanatı Tarihi }\end{array}$ & $\begin{array}{l}\text { Sanat } \\
\text { Tarihi }\end{array}$ & & 6 \\
\hline $\begin{array}{l}\text { Türk Halk Bilimi ve } \\
\text { Geleneksel Türk El } \\
\text { Sanatları }\end{array}$ & + & & $\begin{array}{c}\text { Türk Halk } \\
\text { Bilimi ve El } \\
\text { Sanatları } \\
\end{array}$ & + & & + & & 4 \\
\hline $\begin{array}{l}\text { Genel Türk Tarihi ve } \\
\text { Kültürü }\end{array}$ & & $\begin{array}{l}\text { Türk } \\
\text { Tarihi ve } \\
\text { Kültürü }\end{array}$ & + & $\begin{array}{c}\text { Genel } \\
\text { Türk } \\
\text { Tarihi, } \\
\text { Edebiyatı } \\
\text { ve Kültürü }\end{array}$ & & + & & 4 \\
\hline $\begin{array}{l}\text { Bilimsel Araştırma } \\
\text { Yöntemleri ve Yayın } \\
\text { Etiği }\end{array}$ & & $\begin{array}{c}\text { Sosyal } \\
\text { Bilimlerde } \\
\text { Araştırma } \\
\text { Yöntemleri }\end{array}$ & & $\begin{array}{l}\text { Bilimsel } \\
\text { Araştırma } \\
\text { Yöntemleri } \\
\text { ve Etik }\end{array}$ & + & + & $\begin{array}{c}\text { Nicel } \\
\text { Araştırma } \\
\text { Yöntemleri }\end{array}$ & 5 \\
\hline $\begin{array}{l}\text { Genel Sağlık Bilgisi } \\
\text { ve İlk Yardım }\end{array}$ & $\begin{array}{l}\text { Sağlık } \\
\text { Turizmi ve } \\
\text { Turist } \\
\text { Sağlığı }\end{array}$ & & $\begin{array}{l}\text { Genel Sağlık } \\
\text { ve İlkyardım }\end{array}$ & $\begin{array}{c}\text { Sağlık } \\
\text { Turizmi, } \\
\text { Turist } \\
\text { Sağlığı ve } \\
\text { İlk Yardım }\end{array}$ & & + & & 4 \\
\hline Turizm Sosyolojisi & + & + & & + & & + & & 4 \\
\hline $\begin{array}{l}\text { Rehberlik ve } \\
\text { Gastronomi }\end{array}$ & & & Türk Mutfağı & & + & $\begin{array}{c}\text { Türkiye } \\
\text { Yiyecek } \\
\text { - İçecek } \\
\text { ve } \\
\text { Mutfak } \\
\text { Kültürü }\end{array}$ & & 3 \\
\hline $\begin{array}{l}\text { Seyahat Acentacılığ } \\
\text { ve Tur Operatörlüğü }\end{array}$ & + & & $\begin{array}{c}\text { Seyahat } \\
\text { Acentacilığ } 1 \text {, }\end{array}$ & & + & & & 3 \\
\hline $\begin{array}{l}\text { Tur Organizasyonu ve } \\
\text { Yönetimi }\end{array}$ & + & & $\begin{array}{c}\text { Tur } \\
\text { Planlamas1 } \\
\text { ve Yönetimi }\end{array}$ & & & & & $1(2)$ \\
\hline $\begin{array}{l}\text { Sosyal Sorumluluk ve } \\
\text { Meslek Etiği }\end{array}$ & + & $\begin{array}{c}\text { Turist } \\
\text { Rehberliği } \\
\text { Meslek } \\
\text { Etiği }\end{array}$ & & & & & & 2 \\
\hline $\begin{array}{l}\text { Turizmde Sosyal } \\
\text { Psikoloji }\end{array}$ & & + & & & & & & 1 \\
\hline Özel İlgi Turizmi & & + & + & & & & + & 3 \\
\hline $\begin{array}{l}\text { İnanç Turizmi } \\
\text { Rehberliği }\end{array}$ & & + & & & & & & 1 \\
\hline $\begin{array}{l}\text { Etkinlik Planlaması ve } \\
\text { Yönetimi }\end{array}$ & & + & & & & & & 1 \\
\hline $\begin{array}{l}\text { Rehberlik } \\
\text { Uygulamaları }\end{array}$ & & & + & & & & & 1 \\
\hline Turizm Ekonomisi & & & + & & & & + & 2 \\
\hline Turizm Pazarlaması & & & + & & + & & & 2 \\
\hline $\begin{array}{l}\text { Rehberlik } \\
\text { Yetkinlikleri ve } \\
\text { Mevzuatı }\end{array}$ & & & & & + & & & 1 \\
\hline $\begin{array}{l}\text { Anadolu Tarihi ve } \\
\text { Coğrafyası }\end{array}$ & & & & & + & & & 1 \\
\hline Turizm İşletmeciliği & & & & & + & & & 1 \\
\hline $\begin{array}{l}\text { Ekolojik Okuryazarlık } \\
\text { ve Sürdürülebilirlik }\end{array}$ & & & & & + & & & 1 \\
\hline Turizm Çeşitleri & & & & & & + & & 1 \\
\hline
\end{tabular}

Ak ve Soybalı; Turist Rehberliği Tezsiz Yüksek Lisans Eğitimi: Dersler ve Akademisyenler Üzerine Bir Araştırma/ Non-Thesis Master's Education in Tourist Guidance: A Study on the Lectures and Academicians 
Turist Rehberliği Dergisi (TURED) \& Yıl. 2021, Cilt. 4, Sayı. 2

Journal of Tour Guiding (JOTOG) \& Year. 2021, Volume. 4, Issue. 2

Tablo 4

Turist/Turizm Rehberliği Tezsiz Yüksek Lisans Programlarında Açılan Dersler (2020-2021)

(Devami)

\begin{tabular}{|c|c|c|c|c|c|c|c|c|}
\hline DERSLER & $\begin{array}{c}\text { Afyon } \\
\text { Kocatepe } \\
\text { Ü. }\end{array}$ & $\begin{array}{l}\text { Çanakkale } \\
\text { Onsekiz } \\
\text { Mart Ü. }\end{array}$ & $\begin{array}{l}\text { Eskişehir } \\
\text { Osmangazi } \\
\text { Ü. }\end{array}$ & $\begin{array}{c}\text { İzmir } \\
\text { Katip } \\
\text { Çelebi Ü. }\end{array}$ & $\begin{array}{l}\text { Kapadokya } \\
\text { Ü. }\end{array}$ & $\begin{array}{l}\text { Mardin } \\
\text { Artuklu } \\
\quad \ddot{\text { U. }}\end{array}$ & $\begin{array}{l}\text { Recep } \\
\text { Tayyip } \\
\text { Erdoğan } \\
\text { Ü. }\end{array}$ & $\stackrel{\dot{a}}{\dot{\theta}}$ \\
\hline Turist Davranışları & & & & & & + & $\begin{array}{c}\text { Turizmde } \\
\text { Tüketici } \\
\text { Davranışları }\end{array}$ & 2 \\
\hline $\begin{array}{l}\text { Turizmde Güncel } \\
\text { Sorunlar }\end{array}$ & & & & & & + & & 1 \\
\hline $\begin{array}{l}\text { İş ve Sosyal Güvenlik } \\
\text { Hukuku }\end{array}$ & & & & & & + & & 1 \\
\hline $\begin{array}{l}\text { Girişimcilik ve } \\
\text { Liderlik }\end{array}$ & & & & & & + & & 1 \\
\hline $\begin{array}{l}\text { Kültürel Farklılıkların } \\
\text { Yönetimi }\end{array}$ & & & & & & + & & 1 \\
\hline $\begin{array}{l}\text { Güneydoğu Anadolu } \\
\text { Bölgesi Yerel } \\
\text { Değerleri }\end{array}$ & & & & & & + & & 1 \\
\hline $\begin{array}{l}\text { Turizmde İnsan } \\
\text { Kaynakları Yönetimi }\end{array}$ & & & & & & & + & 1 \\
\hline Sürdürülebilir Turizm & & & & & & & + & 1 \\
\hline TOPLAM & 15 & 16 & 17 & 15 & 11 & 23 & 11 & 108 \\
\hline
\end{tabular}

Kaynak: Üniversitelerin birim web siteleri incelenerek derlenmiştir.

Tablo 4 kapsamında son olarak her üniversitede açılmış olan tek dersin "Mitoloji" olduğu görülmektedir. Bununla birlikte "Sanat Tarihi ve İkonografi", "İletișim Becerileri", "Anadolu Medeniyetleri Tarihi”, “Arkeoloji ve Müzecilik”, "Türkiye'nin Turizm Coğrafyası”, "Dinler Tarihi”, "Genel Turizm Bilgisi ve Turizm Mevzuatı", "Turizm Rehberliği” ve "Bilimsel Araştırma Yöntemleri ve Yayın Etiği" gibi derslerin üniversitelerin ilgili programlarında sıklıkla açılan genel dersler arasında kabul gördügünü söylemek mümkündür. Diğer yandan 16 dersin (Turizmde Sosyal Psikoloji, İnanç Turizmi Rehberliği, Etkinlik Planlaması ve Yönetimi, Rehberlik Uygulamaları, Rehberlik Yetkinlikleri ve Mevzuatı, Anadolu Tarihi ve Coğrafyası, Turizm İşletmeciliği, Ekolojik Okuryazarlık ve Sürdürülebilirlik, Turizm Çeşitleri, Turizmde Güncel Sorunlar, İş ve Sosyal Güvenlik Hukuku, Girișimcilik ve Liderlik, Kültürel Farklılıkların Yönetimi, Güneydoğu Anadolu Bölgesi Yerel Değerleri, Turizmde İnsan Kaynakları Yönetimi, Sürdürülebilir Turizm) ise sadece açıldığı ilgili üniversitede bulunduğu dikkat çekmektedir.

\subsection{Araştırma Kapsamındaki Akademisyenlere İlișkin Tanıtıcı ve İstatistiki Bulgular}

Akademisyenlere ilişkin bulgular kapsamında ilk olarak bulunulan birimlere bakıldığında (Tablo 5) en büyük kısmı, \%56,3 ile turizm fakülteleri oluşturmakta; bu siralamay1 \%14,1 ile fen-edebiyat fakültelerindeki akademisyenler, \%6,3'er oranlarla edebiyat fakülteleri ve uygulamalı bilimler yüksekokullarındaki akademisyenler izlemektedir.

Tablo 5 değerlendirildiğinde akademisyenlerin \%65,6'sının kadrolarının turizmle ilgili birimlerde olduğu, \%34,4'ünün ise turizm dıșı birimlerde görev yaptığı dikkat çekmektedir. Aynı tablo kapsamında akademisyenlerin kadrolarının bulunduğu birimlerdeki bölümlerine bakıldığında \%20,3 ile "Turizm İşletmeciliği" en büyük kısmı oluşturmakta; bu sıralamayı \%15,6'şar oranla "Gastronomi ve Mutfak Sanatları" ve "Turizm Rehberliği" bölümleri ve \%9,4 ile "Seyahat İșletmeciliği ve Turizm Rehberliği”" bölümü izlemektedir. Bu bağlamda akademisyenlerin daha çok turizm birimleri içerisinde fazla farklılık gözetmeden 
Turist Rehberliği Dergisi (TURED) \& Yı1. 2021, Cilt. 4, Sayı. 2

Journal of Tour Guiding (JOTOG) \& Year. 2021, Volume. 4, Issue. 2

yedi farklı bölüm içerisinde yer aldıkları, turizm dışında görev yapan akademisyenlerin ise turizm dışı toplam 14 farklı bölüm ile daha çok çeşitlilik ve farklılık göstermeleriyle birlikte ağırlıklı olarak "Sanat Tarihi”, "Tarih" ve "Arkeoloji” bölümlerinde görev yaptıkları görülmektedir.

Tablo 5

Akademisyenlerin Bulundukları Birim, Bölüm ve Anabilim Dalı/Programa Göre Dağılımı

\begin{tabular}{|c|c|c|c|c|c|c|c|c|c|}
\hline & BİRİM & $\mathbf{f}$ & $\%$ & BÖLÜM & $\mathbf{f}$ & $\%$ & $\begin{array}{c}\text { ANABİLİM } \\
\text { DALI/PROGRAM }\end{array}$ & $\mathbf{f}$ & $\%$ \\
\hline 1 & Turizm Fakültesi* & 36 & 56,3 & Turizm İşletmeciliğgi* & 13 & 20,3 & $\begin{array}{l}\text { Gastronomi ve Mutfak } \\
\text { Sanatlar1* }\end{array}$ & 10 & 15,6 \\
\hline 2 & Fen-Edebiyat Fakültesi & 9 & 14,1 & $\begin{array}{l}\text { Gastronomi ve Mutfak } \\
\text { Sanatları } *\end{array}$ & 10 & 15,6 & Turizm İşletmeciliği* & 10 & 15,6 \\
\hline 3 & Edebiyat Fakültesi & 4 & 6,3 & Turizm Rehberliği* & 10 & 15,6 & Turizm Rehberliği* & 10 & 15,6 \\
\hline 4 & $\begin{array}{l}\text { Uygulamalı Bilimler } \\
\text { Yüksekokulu* }\end{array}$ & 4 & 6,3 & $\begin{array}{l}\text { Seyahat İşletmeciliği } \\
\text { ve Turizm Rehberliği * }\end{array}$ & 6 & 9,4 & $\begin{array}{l}\text { Seyahat İşletmeciliği ve } \\
\text { Turizm Rehberliği* }\end{array}$ & 6 & 9,4 \\
\hline 5 & $\begin{array}{l}\text { Güzel Sanatlar } \\
\text { Fakültesi }\end{array}$ & 3 & 4,7 & Sanat Tarihi & 4 & 6,3 & Konaklama İşletmeciliği* & 3 & 4,7 \\
\hline 6 & $\begin{array}{l}\text { Beşeri Bilimler } \\
\text { Fakültesi }\end{array}$ & 2 & 3,1 & Tarih & 4 & 6,3 & Klasik Arkeoloji & 2 & 3,1 \\
\hline 7 & Meslek Yüksekokulu* & 2 & 3,1 & Arkeoloji & 3 & 4,7 & Anatomi & 1 & 4,7 \\
\hline 8 & Tıp Fakültesi & 1 & 1,6 & El Sanatları & 1 & 1,6 & Biyoenformatik & 1 & 1,6 \\
\hline 9 & Açıköğretim Fakültesi & 1 & 1,6 & $\begin{array}{l}\text { Felsefe ve Din } \\
\text { Bilimleri }\end{array}$ & 1 & 1,6 & Din Bilimleri & 1 & 1,6 \\
\hline 10 & $\begin{array}{l}\text { İktisadi ve İdari } \\
\text { Bilimler Fakültesi }\end{array}$ & 1 & 1,6 & $\begin{array}{l}\text { Geleneksel Türk } \\
\text { Sanatları }\end{array}$ & 1 & 1,6 & $\begin{array}{l}\text { Erken Hristiyan ve Bizans } \\
\text { Sanatları Tarihi }\end{array}$ & 1 & 1,6 \\
\hline 11 & İslami İlimler Fakültesi & 1 & 1,6 & Havacılık Yönetimi* & 1 & 1,6 & Eskiçağ Tarihi & 1 & 1,6 \\
\hline 12 & & & & İlahiyat & 1 & 1,6 & Geleneksel Türk Sanatları & 1 & 1,6 \\
\hline 13 & & & & $\begin{array}{l}\text { İngiliz Dili ve } \\
\text { Edebiyat1 }\end{array}$ & 1 & 1,6 & Genel Türk Tarihi & 1 & 1,6 \\
\hline 14 & & & & İşletme & 1 & 1,6 & Havacılık Yönetimi* & 1 & 1,6 \\
\hline 15 & & & & $\begin{array}{l}\text { Moleküler Biyoloji ve } \\
\text { Genetik }\end{array}$ & 1 & 1,6 & İlahiyat & 1 & 1,6 \\
\hline 16 & & & & $\begin{array}{l}\text { Mütercim ve } \\
\text { Tercümanlık }\end{array}$ & 1 & 1,6 & İngiliz Dili ve Edebiyatı & 1 & 1,6 \\
\hline 17 & & & & $\begin{array}{l}\text { Otel, Lokanta ve İkram } \\
\text { Hizmetleri* }\end{array}$ & 1 & 1,6 & $\begin{array}{l}\text { İngilizce Mütercim ve } \\
\text { Tercümanlık }\end{array}$ & 1 & 1,6 \\
\hline 18 & & & & Resim & 1 & 1,6 & $\begin{array}{l}\text { Protohistorya ve Ön Asya } \\
\text { Arkeoloji }\end{array}$ & 1 & 1,6 \\
\hline 19 & & & & $\begin{array}{l}\text { Seyahat, Turizm ve } \\
\text { Eğlence Hizmetleri* }\end{array}$ & 1 & 1,6 & Resim & 1 & 1,6 \\
\hline 20 & & & & Temel Tıp Bilimleri & 1 & 1,6 & Sanat Tarihi & 1 & 1,6 \\
\hline 21 & & & & Türk Dili ve Edebiyatı & 1 & 1,6 & Sayısal Yöntemler & 1 & 1,6 \\
\hline 22 & & & & & & & Seyahat İşletmeciliği* & 1 & 1,6 \\
\hline 23 & & & & & & & Takı ve Tasarım & 1 & 1,6 \\
\hline 24 & & & & & & & $\begin{array}{l}\text { Turizm ve Otel } \\
\text { İşletmeciliği* }\end{array}$ & 1 & 1,6 \\
\hline 25 & & & & & & & Türk Halk Edebiyatı & 1 & 1,6 \\
\hline 26 & & & & & & & Türk ve İslam Sanatları & 1 & 1,6 \\
\hline 27 & & & & & & & Türk-İslam Sanat Tarihi & 1 & 1,6 \\
\hline 28 & & & & & & & Yakınçağ & 1 & 1,6 \\
\hline 29 & & & & & & & Yeniçağ & 1 & 1,6 \\
\hline \multirow{3}{*}{ ڤं } & \multicolumn{2}{|c|}{ Turizmle Ilgili Birimler (3) } & 42 & $\begin{array}{l}\text { Turizmle Illgili } \\
\text { Birimler (7) }\end{array}$ & & 42 & $\begin{array}{ll}\text { 65,6 } & \text { Turizmle Ilgili } \\
& \text { Birimler }(8)\end{array}$ & 42 & 65,6 \\
\hline & \multicolumn{2}{|c|}{ Turizm Dlşı Birimler (8) } & 22 & $\begin{array}{c}\text { Turizm Dlşl } \\
\text { Birimler (14) }\end{array}$ & & 22 & $\begin{array}{ll}34,4 & \text { Turizm Dlşı } \\
& \text { Birimler (21) }\end{array}$ & 22 & 34,4 \\
\hline & \multicolumn{2}{|l|}{ Tümü (11) } & 64 & Тӥтӥ (21) & & 64 & Тӥтӥ (29) & 64 & 100 \\
\hline
\end{tabular}

*: Turizm ile ilgili birimler 
Turist Rehberliği Dergisi (TURED) \& Yıl. 2021, Cilt. 4, Sayı. 2

Journal of Tour Guiding (JOTOG) \& Year. 2021, Volume. 4, Issue. 2

Tablo 5'te son olarak akademisyenlerin kadrolarının bulunduğu birimlerdeki anabilim dalı ve programları incelendiğinde \%15,6'şar oranlarla "Gastronomi ve Mutfak Sanatları", "Turizm İşletmeciliği” ve "Turizm Rehberliğii" anabilim dallarının öne çıktığı görülmektedir. Bununla birlikte turizm ile ilgili birimlerde görev yapan toplam 42 akademisyen, yedi farkl1 bölümde toplam sekiz farklı anabilim dalında görev yapmaktadır. Dolayısıyla "Konaklama İşletmeciliği”" anabilim dalının "Turizm İşletmeciliği” bölümü kapsamında yer almasının, anabilim dalı ve bölüm sıralamalarının farklılaşmasını etkilediği görülmektedir. Turizm dışındaki birimlerdeki bölümlerin anabilim dalları incelendiğinde ise 14 farklı bölüm içerisinde toplam 21 farklı anabilim dalında görev yaptıkları dikkat çekmektedir. Diğer bir ifadeyle turizm dışı birimlerde görev yapan toplam 22 akademisyenin 21 ' $\mathrm{i}(\% 95,5)$ farklı anabilim dallarında görev yapmaktadırlar.

\section{Tablo 6}

Akademisyenlerin Cinsiyet ve Unvanlarının Dağılımı

\begin{tabular}{|c|c|c|c|c|c|c|c|c|c|c|c|c|c|c|}
\hline \multirow{3}{*}{ UNVAN } & \multicolumn{6}{|c|}{ TURİZMLE İLGILİ BİRIMLER } & \multicolumn{6}{|c|}{ TURİZM DIŞI BİRIMMLER } & \multirow{3}{*}{$\dot{0}$} & \multirow{3}{*}{$\begin{array}{c}\text { Genel } \\
\%\end{array}$} \\
\hline & \multicolumn{2}{|c|}{ Kadın } & \multicolumn{2}{|c|}{ Erkek } & \multicolumn{2}{|c|}{ Toplam } & \multicolumn{2}{|c|}{ Kadın } & \multicolumn{2}{|c|}{ Erkek } & \multicolumn{2}{|c|}{ Toplam } & & \\
\hline & f & $\%$ & $\mathrm{f}$ & $\%$ & $\mathrm{f}$ & $\%$ & $\mathrm{f}$ & $\%$ & $\mathrm{f}$ & $\%$ & $\mathrm{f}$ & $\%$ & & \\
\hline Prof. Dr. & - & - & 9 & 21,4 & 9 & 14,1 & - & - & 4 & 18,2 & 4 & 6,3 & 13 & 20,3 \\
\hline Doç. Dr. & 3 & 7,1 & 10 & 23,8 & 13 & 20,3 & 2 & 9,1 & 5 & 22,7 & 7 & 10,9 & 20 & 31,3 \\
\hline Dr. Öğr. Üyesi & 9 & 21,4 & 11 & 26,2 & 20 & 31,3 & 5 & 22,7 & 5 & 22,7 & 10 & 15,6 & 30 & 46,9 \\
\hline Arş. Gör. Dr. & - & & - & & - & & - & & 1 & 4,5 & 1 & 1,6 & 1 & 1,6 \\
\hline TOPLAM & 12 & 28,6 & 30 & 71,4 & 42 & 65,6 & 7 & 31,8 & 15 & 68,2 & 22 & 34,4 & 64 & 100,0 \\
\hline
\end{tabular}

Tablo 6 kapsamında ilk olarak araştırma kapsamındaki 64 akademisyenin 19'unu $(\% 29,7)$ kadın, 45'ini $(\% 70,3)$ erkek akademisyenlerin oluşturduğu görülmektedir. Dolayısıyla tezsiz yüksek lisans düzeyinde rehberlik eğitiminde erkek akademisyenlerin daha fazla rol aldıkları söylenebilir. Bu durumu Baytok vd. (2019) tarafından yapılan çalışmadaki rehberlik bölümlerindeki profesör, doçent doktor ve doktor öğretim üyesi olan erkek akademisyenlerin kadınlara göre daha fazla oldukları sonucu desteklemektedir. Buna ek olarak akademisyenlerin unvanları incelendiğinde; en büyük çoğunluğu, \%46,9'luk oranıyla Dr. Öğr. Üyesi unvanına sahip akademisyenlerin oluşturduğu görülürken; onu sırasıyla \%31,3'lük oranıyla Doç. Dr. ve \%20,3'lük oranıyla Prof. Dr. unvanına sahip akademisyenler takip etmektedir. Bu sonuç Dr. Öğr. Üyesi unvanlı akademisyenlerin rehberlik bölümlerinde istihdamının artmasıyla (Aylan ve Başoda, 2018) desteklenerek ilişkilendirilebilir. Diğer yandan turist/turizm rehberliği tezsiz yüksek lisans programlarında hiçbir dersin Prof. Dr. unvanına sahip kadın akademisyenler tarafından yürütülmediği de dikkat çekmektedir. Doğancılı ve Karaçar (2018) da araştırmalarında 2018 yılı itibariyle rehberlik bölümlerinde Dr. Öğr. Üyesi unvanlı akademisyenlerin daha fazla olduğuna ve Prof. Dr. kadrosunda herhangi bir kadın akademisyenin yer almadığına ulaşmışlardır. Bu durumda tezsiz yüksek lisans düzeyinde ders yürüten başka birim ve bölümlerde görevli akademisyenler arasında da Prof. Dr. unvanlı kadın akademisyenin olmaması dikkat çekicidir. 
Turist Rehberliği Dergisi (TURED) \& Yıl. 2021, Cilt. 4, Sayı. 2

Journal of Tour Guiding (JOTOG) \& Year. 2021, Volume. 4, Issue. 2

Tablo 7

Akademisyenlerin Yürüttükleri Derslerin Unvanlara Göre Dağılımı

\begin{tabular}{|c|c|c|c|c|c|c|c|c|}
\hline \multirow{2}{*}{ DERSLER } & \multicolumn{3}{|c|}{$\begin{array}{l}\text { TURİZMLE İLGİLI } \\
\text { BİRIMLER }\end{array}$} & \multicolumn{4}{|c|}{$\begin{array}{l}\text { TURİZM DIŞI } \\
\text { BİRİMLER }\end{array}$} & \multirow{2}{*}{$\stackrel{\ominus}{\ominus}$} \\
\hline & $\begin{array}{l}\text { Prof. } \\
\text { Dr. }\end{array}$ & $\begin{array}{l}\text { Doç. } \\
\text { Dr. }\end{array}$ & $\begin{array}{l}\text { Dr.Öğr. } \\
\text { Üyesi }\end{array}$ & $\begin{array}{l}\text { Prof. } \\
\text { Dr. }\end{array}$ & $\begin{array}{l}\text { Doç. } \\
\text { Dr. }\end{array}$ & $\begin{array}{l}\text { Dr.Öğr. } \\
\text { Üyesi }\end{array}$ & $\begin{array}{l}\text { Arş. } \\
\text { Gör. }\end{array}$ & \\
\hline Turizm Rehberlik Mesleği ve Meslek Etiği & 2 & 3 & 4 & & & & & 9 \\
\hline Mitoloji & 1 & 1 & 3 & & & 2 & & 7 \\
\hline Arkeoloji ve Müzecilik & 1 & & 2 & & & 3 & & 6 \\
\hline Anadolu Medeniyetleri Tarihi & 1 & 2 & 1 & & 2 & & & 6 \\
\hline Sanat Tarihi & & 1 & 1 & & 2 & 2 & & 6 \\
\hline Türkiye Turizm Coğrafyası & & 2 & 3 & & & & & 5 \\
\hline Bilimsel Araştırma Yöntemleri ve Etik & 1 & & 3 & 1 & & & & 5 \\
\hline Dinler Tarihi & 1 & 1 & & 2 & 1 & & & 5 \\
\hline Genel Turizm Bilgisi ve Turizm Mevzuatı & 2 & 1 & 2 & & & & & 5 \\
\hline Genel ve Mesleki İletişim Becerileri & 1 & 2 & 2 & & & & & 5 \\
\hline Türk Halk Bilimi ve El Sanatları & & & 1 & & 1 & 2 & & 4 \\
\hline Sağlık Turizmi, Turist Sağlığı ve İlk Yardım & 1 & 2 & & & & & 1 & 4 \\
\hline Turizm Sosyolojisi & 2 & & 2 & & & & & 4 \\
\hline Türkiye Flora Faunası ve Doğa Tarihi & & 1 & 1 & 1 & & & & 3 \\
\hline Genel Türk Tarihi ve Kültürü & & & 1 & & 1 & 1 & & 3 \\
\hline Özel İlgi Turizmi & & 2 & 1 & & & & & 3 \\
\hline $\begin{array}{l}\text { Türkiye Yiyecek - İçecek ve Mutfak } \\
\text { Kültürü }\end{array}$ & & 2 & & & & & & 2 \\
\hline Turizm Pazarlaması & & 1 & 1 & & & & & 2 \\
\hline Seyahat Acentacılığı ve Tur Operatörlüğü & & 1 & 1 & & & & & 2 \\
\hline Turizm Ekonomisi & 1 & & 1 & & & & & 2 \\
\hline $\begin{array}{l}\text { Türkiye Turizm Coğrafyası, Flora ve } \\
\text { Faunası }\end{array}$ & & 1 & & & & & & 1 \\
\hline Anadolu Tarihi ve Coğrafyası & 1 & & & & & & & 1 \\
\hline Ekolojik Okuryazarlık ve Sürdürülebilirlik & & & & & & 1 & & 1 \\
\hline $\begin{array}{l}\text { Seyahat Acentacılığı, Tur Planlaması ve } \\
\text { Yönetimi }\end{array}$ & & 1 & & & & & & 1 \\
\hline İnanç Turizmi Rehberliği & & 1 & & & & & & 1 \\
\hline Etkinlik Planlaması ve Yönetimi & & 1 & & & & & & 1 \\
\hline Turizmde Sosyal Psikoloji & & 1 & & & & & & 1 \\
\hline Girişimcilik ve Liderlik & & 1 & & & & & & 1 \\
\hline Sosyal Sorumluluk ve Meslek Etiği & & 1 & & & & & & 1 \\
\hline Turizm İşletmeciliği & 1 & & & & & & & 1 \\
\hline Turizmde İnsan Kaynakları Yönetimi & & & 1 & & & & & 1 \\
\hline Sürdürülebilir Turizm & & & 1 & & & & & 1 \\
\hline Turizmde Tüketici Davranışları & & & 1 & & & & & 1 \\
\hline Turizm Çeşitleri & & & 1 & & & & & 1 \\
\hline Turist Davranışları & & & 1 & & & & & 1 \\
\hline Turizmde Güncel Sorunlar & & & 1 & & & & & 1 \\
\hline İş ve Sosyal Güvenlik Hukuku & & & 1 & & & & & 1 \\
\hline Kültürel Farklılıkların Yönetimi & & & 1 & & & & & 1 \\
\hline $\begin{array}{l}\text { Güneydoğu Anadolu Bölgesi Yerel } \\
\text { Değerleri }\end{array}$ & & & 1 & & & & & 1 \\
\hline Tur Organizasyonu ve Yönetimi & & & 1 & & & & & 1 \\
\hline \multirow{3}{*}{ TOPLAM } & 16 & 29 & 40 & 4 & 7 & 11 & 1 & \multirow{3}{*}{108} \\
\hline & $\% 18,8$ & $\% 34,1$ & $\% 47,1$ & $\% 17,4$ & $\% 30,4$ & $\% 47,8$ & $\% 4,4$ & \\
\hline & \multicolumn{3}{|c|}{$85(\% 78,7)$} & \multicolumn{4}{|c|}{$23(21,3)$} & \\
\hline
\end{tabular}




\section{IIIII)}

Turist Rehberliği Dergisi (TURED) \& Yıl. 2021, Cilt. 4, Sayı. 2

Journal of Tour Guiding (JOTOG) \& Year. 2021, Volume. 4, Issue. 2

Tablo 7'de turizm birimlerindeki akademisyenlerin girmiş oldukları derslerin (toplam 85 adet) \%18,8'inin Prof. Dr. unvanlı; \%34,1'inin Doç. Dr. unvanlı; \%47,1'inin de Dr. Öğr. Üyesi unvanlı akademisyenler tarafından yürütüldüğü dikkat çekmektedir. Diğer yandan turizm dışı birimlerde görevli akademisyenlerin girmiş oldukları derslerin (toplam 23 adet) ise \%17,4'ünü Prof. Dr. unvanl1; \%30,4'ünü Doç. Dr. unvanl1; \%47,8'ini Dr. Öğr. Üyesi unvanlı; \%4,4'ün de Arş. Gör. Dr. unvanlı akademisyenler yürütmektedirler. Sonuç itibariyle araştırma kapsamındaki toplam 108 dersin 20'si (\%18,5) Prof. Dr. unvanlı; 36’s1 (\%33,3) Doç. Dr. unvanlı; 51'i $(\% 47,2)$ Dr. Öğr. Üyesi unvanlı; biri de Arş. Gör. Dr. unvanlı akademisyenler tarafindan yürütülmektedir.

Tablo 7'de ayrıca turizm alanındaki akademisyenlerin ağırlıklı olarak "Genel Turizm Bilgisi ve Turizm Mevzuatı", "Turizm Rehberliği”, "Türkiye'nin Turizm Coğrafyası", "Mitoloji" ve "İletişim Becerileri” derslerine yöneldikleri görülse de ilgili akademik yılda verildiği saptanan toplam 39 ders grubunun neredeyse tamamını (38) yürütebiliyor olmaları dikkat çekicidir. Turist/turizm rehberliği programlarında kadrosu turizm dışı birimlerde bulunan akademisyenlerin ise ağırlıklı olarak "Sanat Tarihi ve İkonografi", "Arkeoloji ve Müzecilik", "Dinler Tarihi”, "Türk Halk Bilimi ve Geleneksel Türk El Sanatları”, "Anadolu Medeniyetleri Tarihi”, "Mitoloji" ve "Genel Türk Tarihi ve Kültürü" derslerini yürüttükleri görülmektedir.

\subsection{Ders Yürüten Akademisyenlerin Yayınlarına İlişsin İstatistiki Bulgular}

Ders yürüten akademisyenlerin yayınlarına ilişkin ilk olarak Tablo 8 'de unvan ve cinsiyete göre yayınların dağılımı ve aritmetik ortalamaları yer almaktadır. Tabloda turizmle ilgili birimlerdeki akademisyenler arasında Prof. Dr. unvanlı akademisyenlerin makale ortalaması 30,9; kitap ortalaması 2,6; kitap bölümü ortalaması 14,7 ve bildiri ortalaması 30,8 olarak görülmektedir. Turizm dıș birimlerde görev yapan Prof. Dr. unvanlı akademisyenlerin ise makale ortalaması 20; kitap ortalaması 3; kitap bölümü ortalaması 8,3; bildiri ortalaması 11,9 olarak dikkat çekmektedir. Genel olarak değerlendirildiğinde ise Prof. Dr. unvanlı akademisyenlerin toplam 882 yayını ve 67,8 yayın ortalaması bulunmaktadır. Diğer yandan turizmle ilgili birimlerdeki akademisyenler arasında Doç. Dr. unvanlı akademisyenlerin makale ortalaması 27,3; kitap ortalaması 1,3; kitap bölümü ortalaması 10,4 ve bildiri ortalaması 23,5 olarak görülmektedir. Turizm dışı birimlerde görev yapan Doç. Dr. unvanlı akademisyenlerin ise makale ortalaması 13,8; kitap ortalaması 1,7; kitap bölümü ortalaması 7,4; bildiri ortalamas 11,3 olarak dikkat çekmektedir. Genel olarak değerlendirildiğinde ise Doç. Dr. unvanlı akademisyenlerin toplam 1051 yayını ve 52,6 yayın ortalaması bulunmaktadır. Son olarak turizmle ilgili birimlerdeki akademisyenler arasında Dr. Öğr. Üyesi unvanlı akademisyenlerin makale ortalaması 9,2; kitap ortalaması 0,3; kitap bölümü ortalamas 5,4 ve bildiri ortalaması 14,5 olarak görülmektedir. Turizm dışı birimlerde görev yapan Dr. Öğr. Üyesi unvanlı akademisyenlerin ise makale ortalaması 6,6; kitap ortalaması 0,8; kitap bölümü ortalaması 2,9; bildiri ortalaması 4,8 olarak dikkat çekmektedir. Genel olarak değerlendirildiğinde ise Dr. Öğr. Üyesi unvanlı akademisyenlerin toplam 667 yayını ve 22,2 yayın ortalaması bulunmaktadır. Ayrıca Arş. Gör. Dr. unvanlı akademisyenin ise 6 makalesi ve 18 bildirisi olduğu dikkat çekmektedir. 
Turist Rehberliği Dergisi (TURED) \& Yıl. 2021, Cilt. 4, Sayı. 2

Journal of Tour Guiding (JOTOG) \& Year. 2021, Volume. 4, Issue. 2

Tablo 8

Akademisyenlerin Yayınlarının Dağılımı

\begin{tabular}{|c|c|c|c|c|c|c|c|c|c|c|c|c|c|c|c|c|c|c|c|}
\hline \multirow{3}{*}{\multicolumn{2}{|c|}{ DEĞİSSEN }} & \multicolumn{8}{|c|}{ TURIZZMLE İLGİLI BİRIMLER } & \multicolumn{8}{|c|}{ TURİZM DIŞI BİRİMLER } & \multirow{3}{*}{$\begin{array}{c}\text { Top. } \\
\\
\text { \# }\end{array}$} & \multirow{3}{*}{$\begin{array}{c}\text { Genel } \\
\bar{X}\end{array}$} \\
\hline & & \multicolumn{2}{|c|}{ Makale } & \multicolumn{2}{|c|}{ Kitap } & \multicolumn{2}{|c|}{ Kitap B. } & \multicolumn{2}{|c|}{ Bildiri } & \multicolumn{2}{|c|}{ Makale } & \multicolumn{2}{|c|}{ Kitap } & \multicolumn{2}{|c|}{ Kitap B. } & \multicolumn{2}{|c|}{ Bildiri } & & \\
\hline & & \# & $\overline{\mathrm{X}}$ & \# & $\overline{\mathrm{X}}$ & $\#$ & $\overline{\mathrm{X}}$ & $\#$ & $\overline{\mathrm{X}}$ & $\#$ & $\overline{\mathrm{X}}$ & $\#$ & $\bar{X}$ & $\#$ & $\overline{\mathrm{X}}$ & \# & $\overline{\mathrm{X}}$ & & \\
\hline \multirow{4}{*}{ 交 } & $\begin{array}{l}\text { Prof. } \\
\text { Dr. } \\
(9+4=13)\end{array}$ & 278 & 30,9 & 23 & 2,6 & 132 & 14,7 & 277 & 30,8 & 80 & 20,0 & 12 & 3,0 & 33 & 8,3 & 47 & 11,8 & 882 & 67,8 \\
\hline & $\begin{array}{l}\text { Doç. } \\
\text { Dr. } \\
(13+7=20)\end{array}$ & 355 & 27,3 & 17 & 1,3 & 135 & 10,4 & 305 & 23,5 & 96 & 13,8 & 12 & 1,7 & 52 & 7,4 & 79 & 11,3 & 1051 & 52,6 \\
\hline & $\begin{array}{l}\text { Dr. Öğr. } \\
\text { Üyesi } \\
(20+10=30)\end{array}$ & 183 & 9,2 & 6 & 0,3 & 107 & 5,4 & 230 & 11,5 & 66 & 6,6 & 8 & 0,8 & 29 & 2,9 & 48 & 4,8 & 667 & 22,2 \\
\hline & $\begin{array}{l}\text { Arş. } \\
\text { Gör. Dr. } \\
\text { (1) }\end{array}$ & - & - & - & - & - & - & - & - & 6 & 6,0 & - & - & - & - & 18 & 18,0 & 24 & 24,0 \\
\hline \multirow{2}{*}{ 空 } & $\begin{array}{l}\text { Kadın } \\
(12+7=19)\end{array}$ & 131 & 10,9 & 2 & 0,2 & 67 & 5,6 & 196 & 16,3 & 47 & 6,7 & 3 & 0,4 & 13 & 1,9 & 52 & 7,4 & 511 & 26,9 \\
\hline & $\begin{array}{l}\text { Erkek } \\
(30+15=45)\end{array}$ & 685 & 22,8 & 44 & 1,5 & 307 & 10,2 & 616 & 20,5 & 201 & 13,4 & 29 & 1,9 & 101 & 6,7 & 140 & 9,3 & 2113 & 47,0 \\
\hline \multicolumn{2}{|c|}{$\begin{array}{l}\text { TOPLAM } \\
\text { (64) }\end{array}$} & 816 & 19,4 & 46 & 1,1 & 374 & 8,9 & 812 & 19,3 & 248 & 11,3 & 32 & 1,5 & 114 & 5,2 & 192 & 8,7 & 2624 & 41,0 \\
\hline
\end{tabular}

İlgili tabloda (Tablo 8) turizmle ilgili birimlerdeki akademisyenler arasında kadın akademisyenlerin makale ortalaması 10,9; kitap ortalaması 0,2; kitap bölümü ortalaması 5,6 ve bildiri ortalaması 16,3 olarak (toplam 33) görülmektedir. Turizm dışı birimlerde görev yapan kadın akademisyenlerin ise makale ortalamas 16,7 ; kitap ortalaması 0,4 ; kitap bölümü ortalaması 1,9; bildiri ortalamas 7,4 olarak (toplam 16,4) dikkat çekmektedir. Genel olarak değerlendirildiğinde ise kadın akademisyenlerin toplam 511 yayını ve 26,9 yayın ortalaması bulunmaktadır. Öte taraftan turizmle ilgili birimlerdeki akademisyenler arasında erkek akademisyenlerin makale ortalaması 22,8; kitap ortalaması 1,5; kitap bölümü ortalaması 10,2 ve bildiri ortalaması 20,5 olarak (toplam 55) görülmektedir. Turizm dışı birimlerde görev yapan erkek akademisyenlerin ise makale ortalaması 13,4; kitap ortalaması 1,9; kitap bölümü ortalamas 16,7; bildiri ortalamas1 9,3 olarak (toplam 31,3) dikkat çekmektedir. Genel olarak değerlendirildiğinde ise erkek akademisyenlerin toplam 2113 yayını ve 47 yayın ortalaması bulunmaktadır. Bu bulgulara paralel olarak Boyraz ve Kabakulak (2020) çalışmalarında akademisyenlerin cinsiyetlerine göre ortalama yayın sayılarının dağılımında bu yönde fark olduğunu tespit etmişlerdir. Bu bağlamda erkek akademisyenlerin yayın performansının kadın akademisyenlere kıyasla daha yüksek olduğu söylenebilir.

Tablo 8'de turizmle ilgili birimlerdeki akademisyenlerin makale ortalamas1 19,4; kitap ortalaması 1,1; kitap bölümü ortalaması 8,9 ve bildiri ortalaması 19,3 olmak üzere toplam 48,7 yayın ortalaması dikkat çekmektedir. Turizm dışı birimlerdeki akademisyenlerin ise makale ortalamas1 11,3; kitap ortalamas1 1,5; kitap bölümü ortalamas1 5,2 ve bildiri ortalaması 8,7 olmak üzere toplam yayın ortalamaları 26,7 olarak hesaplanmaktadır. Bu durumda turizm dış1 birimlerdeki akademisyenlerin yayın ortalamalarının daha düşük olduğu söylenebilir. Genel olarak ise akademisyenlerin toplam 2624 yayını ve 41 yayın ortalaması olduğu görülmektedir. 
Turist Rehberliği Dergisi (TURED) \& Yı1. 2021, Cilt. 4, Sayı 2

Journal of Tour Guiding (JOTOG) \& Year. 2021, Volume. 4, Issue. 2

Tablo 9

Turizm Alanındaki Akademisyenlerin Yayınlarında Alan Dağılımı

\begin{tabular}{|c|c|c|c|c|c|c|c|c|c|c|}
\hline \multirow{2}{*}{ TÜR } & \multirow{2}{*}{\multicolumn{2}{|c|}{ DEĞİŞKEN }} & \multicolumn{2}{|c|}{ Turizm } & \multicolumn{2}{|c|}{ Rehberlik } & \multicolumn{2}{|c|}{ Diğger } & \multicolumn{2}{|c|}{ Toplam } \\
\hline & & & $\#$ & $\overline{\mathrm{X}}$ & $\#$ & $\overline{\mathrm{X}}$ & $\#$ & $\overline{\mathrm{X}}$ & $\#$ & $\overline{\mathrm{X}}$ \\
\hline \multirow{12}{*}{ 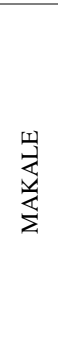 } & \multirow{3}{*}{ Unvan } & Prof. Dr. (9) & 243 & 27,0 & 12 & 1,3 & 23 & 2,6 & 278 & 30,9 \\
\hline & & Doç. Dr. (13) & 299 & 23,0 & 24 & 1,8 & 32 & 2,5 & 355 & 27,3 \\
\hline & & Dr. Öğr. Üyesi (20) & 159 & 8,0 & 11 & 0,6 & 13 & 0,7 & 183 & 9,2 \\
\hline & \multirow{2}{*}{ Cinsiyet } & Kadın (12) & 92 & 7,7 & 6 & 0,5 & 33 & 2,8 & 131 & 10,9 \\
\hline & & Erkek (30) & 609 & 20,3 & 41 & 1,4 & 35 & 1,2 & 685 & 22,8 \\
\hline & \multirow{4}{*}{ Lisans } & Turizm (27) & 545 & 20,2 & 22 & 0,8 & 7 & 0,3 & 574 & 21,3 \\
\hline & & Rehberlik (6) & 73 & 12,2 & 18 & 3,0 & 5 & 0,8 & 96 & 16,0 \\
\hline & & İşletme (5) & 80 & 16,0 & 7 & 1,4 & 22 & 4,4 & 109 & 21,8 \\
\hline & & Diğer (4) & 3 & 0,8 & - & - & 34 & 8,5 & 37 & 9,3 \\
\hline & \multirow{2}{*}{ İdari Görev } & $\operatorname{Var}(21)$ & 434 & 20,7 & 25 & 1,2 & 59 & 2,8 & 518 & 24,7 \\
\hline & & Yok (21) & 267 & 12,7 & 22 & 1,0 & 9 & 0,4 & 298 & 14,2 \\
\hline & \multirow{4}{*}{ Unvan } & LAM (42) & 701 & 16,7 & 47 & 1,1 & 58 & 1,4 & 816 & 19,4 \\
\hline \multirow{12}{*}{$\stackrel{\Xi}{\stackrel{\Xi}{\Xi}}$} & & Prof. Dr. (9) & 20 & 2,2 & - & - & 2 & 0,3 & 23 & 2,6 \\
\hline & & Doç. Dr. (13) & 13 & 1,0 & 2 & 0,2 & 2 & 0,2 & 17 & 1,3 \\
\hline & & Dr. Öğr. Üyesi (20) & 4 & 0,2 & - & - & 2 & 0,1 & 6 & 0,3 \\
\hline & \multirow{2}{*}{ Cinsiyet } & Kadın (12) & 2 & 0,2 & - & - & - & - & 2 & 0,2 \\
\hline & & Erkek (30) & 35 & 1,2 & 2 & 0,1 & 7 & 0,2 & 44 & 1,5 \\
\hline & \multirow{4}{*}{ Lisans } & Turizm (27) & 30 & 1,1 & - & - & 2 & 0,1 & 32 & 1,2 \\
\hline & & Rehberlik (6) & - & - & 2 & 0,3 & 2 & 0,3 & 4 & 0,7 \\
\hline & & İşletme (5) & 7 & 1,4 & - & - & 3 & 0,6 & 10 & 2,0 \\
\hline & & Diğer (4) & - & - & - & - & - & - & - & - \\
\hline & \multirow{2}{*}{ İdari Görev } & $\operatorname{Var}(21)$ & 15 & 0,7 & - & - & 4 & 0,2 & 19 & 0,9 \\
\hline & & Yok (21) & 22 & 1,0 & 2 & 0,1 & 3 & 0,1 & 27 & 1,3 \\
\hline & \multirow{4}{*}{ Unvan } & PLAM (42) & 37 & 0,9 & 2 & 0,0 & 7 & 0,2 & 46 & 1,1 \\
\hline \multirow{12}{*}{ 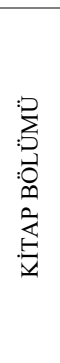 } & & Prof. Dr. (9) & 113 & 12,6 & 9 & 1,0 & 10 & 1,1 & 132 & 14,7 \\
\hline & & Doç. Dr. (13) & 117 & 9,0 & 13 & 1,0 & 5 & 0,4 & 135 & 10,4 \\
\hline & & Dr. Öğr. Üyesi (20) & 90 & 4,5 & 11 & 0,6 & 6 & 0,3 & 107 & 5,4 \\
\hline & \multirow{2}{*}{ Cinsiyet } & Kadın (12) & 59 & 4,9 & 6 & 0,5 & 2 & 0,2 & 67 & 5,6 \\
\hline & & Erkek (30) & 261 & 8,7 & 27 & 0,9 & 19 & 0,6 & 307 & 10,2 \\
\hline & & Turizm (27) & 231 & 8,6 & 20 & 0,7 & 14 & 0,5 & 265 & 9,8 \\
\hline & & Rehberlik (6) & 47 & 7,8 & 11 & 1,8 & - & - & 58 & 9,7 \\
\hline & Lisans & İşletme (5) & 34 & 6,8 & 2 & 0,4 & 3 & 0,6 & 39 & 7,8 \\
\hline & & Diğer (4) & 8 & 2,0 & - & - & 4 & 1,0 & 12 & 3,0 \\
\hline & & Var (21) & 195 & 9,3 & 14 & 0,7 & 17 & 0,8 & 226 & 10,8 \\
\hline & Idari Görev & Yok (21) & 125 & 6,0 & 19 & 0,9 & 4 & 0,2 & 148 & 7,0 \\
\hline & & PLAM (42) & 320 & 7,6 & 33 & 0,8 & 21 & 0,5 & 374 & 8,9 \\
\hline & & Prof. Dr. (9) & 252 & 28,0 & 10 & 1,1 & 15 & 1,7 & 277 & 30,8 \\
\hline & Unvan & Doç. Dr. (13) & 249 & 19,2 & 18 & 1,4 & 38 & 2,9 & 305 & 23,5 \\
\hline & & Dr. Öğr. Üyesi (20) & 174 & 8,7 & 16 & 0,8 & 40 & 2,0 & 230 & 11,5 \\
\hline & & Kadın (12) & 122 & 10,2 & 4 & 0,3 & 70 & 5,8 & 196 & 16,3 \\
\hline & Cinsiyet & Erkek (30) & 553 & 18,4 & 40 & 1,3 & 23 & 0,8 & 616 & 20,5 \\
\hline$\stackrel{=}{=}$ & & Turizm (27) & 510 & 18,9 & 21 & 0,8 & 10 & 0,4 & 541 & 20,0 \\
\hline . & & Rehberlik (6) & 67 & 11,2 & 19 & 3,2 & - & - & 86 & 14,3 \\
\hline & Lisans & İşletme (5) & 83 & 16,6 & 4 & 0,8 & 9 & 1,8 & 96 & 19,2 \\
\hline & & Diğer (4) & 15 & 3,8 & - & - & 74 & 18,5 & 89 & 22,3 \\
\hline & & Var (21) & 452 & 21,6 & 20 & 1,0 & 91 & 4,3 & 563 & 26,8 \\
\hline & Idari Görev & Yok (21) & 223 & 10,6 & 24 & 1,1 & 2 & 0,1 & 249 & 11,9 \\
\hline & & PLAM (42) & 675 & 16,1 & 44 & 1,0 & 93 & 2,2 & 812 & 19,3 \\
\hline
\end{tabular}

Tablo 9'da unvan, cinsiyet, lisans mezuniyeti ve idari görev durumuna göre turizmle ilgili birimlerdeki akademisyenlerin yayınlarının alan dağılımı yer almaktadır. İlk olarak yayınlar unvana göre değerlendirildiğinde Prof. Dr. unvanlı akademisyenlerin turizm alanındaki makalelerinin ortalaması 27; kitaplarının ortalaması 2,2; kitap bölümlerinin ortalaması 12,6; bildirilerinin ortalaması 28 olarak üstünlük göstererek dikkat çekmektedir. Doç. Dr. unvanlı akademisyenlerin ise rehberlik alanındaki makalelerinin ortalaması 1,8 ; kitaplarının ortalaması 0,2 ; kitap bölümlerinin ortalaması 1; bildirilerinin ortalamas 1 1,4 olarak diğer unvanların ortalamalarına kıyasla daha göze çarpmaktadır. Tablo cinsiyete göre yorumlandığında erkek akademisyenlerin turizm ve rehberlik alanlarında tüm yayın türlerindeki ortalamalarının kadın akademisyenlere kıyasla yüksek olduğu dikkat çekmektedir. Makaleler lisans mezuniyetine göre değerlendirildiğinde turizm alanında lisans mezuniyeti 
Turist Rehberliği Dergisi (TURED) \& Yıl. 2021, Cilt. 4, Sayı. 2

Journal of Tour Guiding (JOTOG) \& Year. 2021, Volume. 4, Issue. 2

bulunan akademisyenlerin turizm alanındaki makalelerinin ortalaması 20,2; rehberlik alanında lisans mezuniyeti bulunan akademisyenlerin rehberlik alanındaki makalelerinin ortalamas 3 olarak dikkat çekmektedir. Diğer yayın türlerinde de lisans mezuniyeti istatistiklerinin benzer olduğu görülmektedir. Son olarak makaleler, idari göreve göre değerlendirildiğinde turizmle ilgili birimlerde görev yapan ve herhangi bir idari görevi bulunan akademisyenlerin turizm alanındaki makalelerinin ortalaması 20,7; rehberlik alanındaki makalelerinin ortalamas 1,2 ve diğer alanlardaki makalelerinin ortalaması 2,8 olarak dikkat çekmektedir.

Tablo 10

Turizm Alanındaki Akademisyenlerin Yönettikleri Lisansüstü Tezlerin Alan Dağılımı

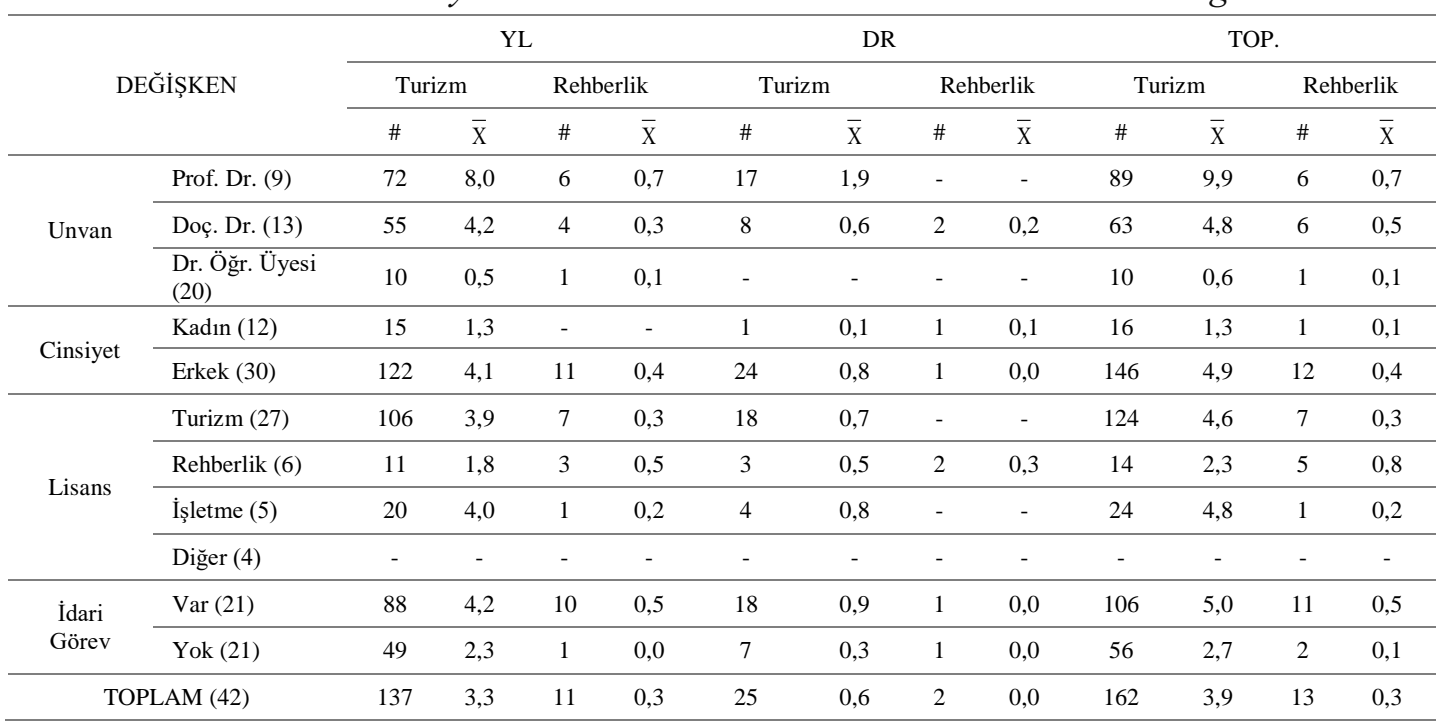

Tablo 10'da unvan, cinsiyet, lisans mezuniyeti ve idari görev durumlarına göre turizm alanındaki akademisyenlerin yönetmiş oldukları lisansüstü tezlerin konusal olarak alan dağılımları yer almaktadır. Öncelikle toplam 175 lisansüstü tezin 162'sinin turizm, 13'ünün rehberlik alanında olduğu görülmektedir. Bu bağlamda Prof. Dr. unvanlı akademisyenler tarafından yönetilmiș lisansüstü tezlerin 89'u (ortalama 9,9) turizm alanında, altısı (ortalama 0,7 ) rehberlik alanındadır. Doç. Dr. unvanına sahip akademisyenler tarafından da 63 (ortalama 4,8) turizm alanında, altı (ortalama 0,5) rehberlik alanında lisansüstü tez yönetilmiştir. Dr. Öğr. Üyesi olan akademisyenlerin ise 10 'u (ortalama 0,6 ) turizm alanında biri (ortalama 0,1 ) rehberlik alanında toplam 11 adet lisansüstü tez yürüttükleri görülmektedir. Ayrıca tablo cinsiyete göre değerlendirildiğinde kadın akademisyenler tarafından yönetilen lisansüstü tezlerin 16's1 (ortalama 1,3) turizm alanında, sadece biri (ortalama 0,1 ) rehberlik alanındadır. Erkek akademisyenlerin ise rehberlik alanında 12 (ortalama 0,4), turizm alanında 146 (ortalama 4,9) adet tez yönettikleri görülmektedir. Bu bağlamda lisansüstü tezlerin büyük çoğunluğunun unvan açısından Prof. Dr. unvanına sahip akademisyenler, cinsiyet açısından ise erkek akademisyenler tarafından yürütüldüğü çekmektedir. Unvan ve cinsiyet bağlamındaki bu bulgular, Boyraz ve Kabakulak (2020) tarafindan yapılan araştırma sonuçlarıyla da paralellik göstermektedir.

İlgili tablo (Tablo 10) lisans mezuniyeti kapsamında ele alındığında lisansüstü tezlerin 4,6 tez ortalaması ile herhangi bir turizm alanında mezuniyeti bulunan akademisyenler tarafından ağırlıklı olarak yürütüldüğü dikkat çekmektedir. İşletme bölümü mezunu 


\section{IIIII)}

Turist Rehberliği Dergisi (TURED) \& Yıl. 2021, Cilt. 4, Sayı. 2

Journal of Tour Guiding (JOTOG) \& Year. 2021, Volume. 4, Issue. 2

akademisyenlerin de turizm alanında 4,8 ortalama ile sıklıkla tez yönettikleri görülmektedir. Rehberlik alanında lisans mezuniyeti bulunan akademisyenlerin ise turizm alanında yönettikleri tez ortalaması (ortalama 2,8) diğerlerine kıyasla düşük olsa da rehberlik alanındaki ortalaması $(0,8)$ dikkat çekmektedir. Tablo son olarak idari görev durumu bağlamında incelendiğinde idari görevi bulunan akademisyenlerin turizm ve rehberlik alanında daha yüksek ortalama ile daha çok lisansüstü tez yönettikleri dikkat çekmektedir.

\section{Sonuç ve Öneriler}

Bu araştırmaya, Türkiye'de turizm alanındaki paydaşların lisansüstü düzeyindeki rehberlik programlarına yönelik görüş ve eleştirileri ş̧ı̆̆ında tezsiz yüksek lisans düzeyinde sürdürülen turist rehberliği eğitimini incelemek düşüncesiyle başlanmıştır. Bu kapsamda araştırmada 2020-2021 akademik yılında ilgili programlarda açılan dersler ve ders yürüten akademisyenler bazı değişkenler bağlamında incelenmiştir.

$\mathrm{Bu}$ araştırmada öncelikle Türkiye'de 2020-2021 akademik yılında altı devlet üniversitesi (Afyon Kocatepe Üniversitesi, Canakkale Onsekiz Mart Üniversitesi, Eskișehir Osmangazi Üniversitesi, İzmir Katip Çelebi Üniversitesi, Mardin Artuklu Üniversitesi, Recep Tayyip Erdoğan Üniversitesi) ve bir özel üniversite (Kapadokya Üniversitesi) olmak üzere toplam yedi üniversitede tezsiz yüksek lisans düzeyindeki turist/turizm rehberliği programında eğitimin aktif olarak sürdürüldüğü görülmüştür. Araştırma kapsamında üniversitelerde rehberlik programlarının isimlendirilmesinde "turist rehberliği”" ve "turizm rehberliğil" olarak ikiye bölünme söz konusu olmuş, dört programın "turist rehberliği”, üç programın ise "turizm rehberliği" olarak isimlendirildiği tespit edilmiştir. Ayrıca turist/turizm rehberliği programlarının farklı enstitüler bünyesinde farklı anabilim dalları altında (Turist/Turizm Rehberliği, Seyahat İşletmeciliği ve Turizm Rehberliği, Turizm İşletmeciliği) altında açıldıkları görülmüştür. $\mathrm{Bu}$ noktada program isimlerinde bölünmenin anabilim dalı kapsamında da söz konusu olduğu söylenebilir. Bu bağlamda Eser (2020) de "Turist Rehberliği" veya "Turizm Rehberliği” program adlarının hangisinin kullanılması gerektiğinin belirlenememesinin yanında anabilim dalları ve program adlarının da farklılık göstermesini, alana özgü terminoloji kısmının kesinlik kazanmadığının bir göstergesi olarak değerlendirmiştir.

Araştırma dâhilindeki yedi üniversitede yürütülen dersler arasında program ve müfredat bağlamında bir bütünlükten ziyade farkl1lıktan bahsetmek mümkündür. Ancak ilgili dersler, Turist Rehberliği Meslek Yönetmeliği (2014) kapsamında belirtilen sertifika programlarında okutulması zorunlu derslerle ağırlıklı olarak bağdaşmaktadır. Söz konusu derslerin ise genel olarak turizm alanındaki akademisyenler tarafindan yürütülmesi/yürütülebilmesi dikkat çekici olsa da turizm dışı birimlerde görev yapan akademisyenler de ilgili programlarda önemli oranda ders yürütmektedirler. Bu bağlamda rehberlik eğitiminin birçok alanı kapsaması neticesinde tezsiz yüksek lisans düzeyinde farklı alanlardan akademisyen istihdamının önemli düzeyde olduğu söylenebilir.

Tezsiz yüksek lisans düzeyindeki turist rehberliği eğitiminde turizm fakültelerinde görev yapan akademisyenler, erkek akademisyenler ve Dr. Öğr. Üyesi unvanlı akademisyenler daha fazla ders yürütmektedirler. Ayrıca erkek akademisyenlerin yayın ve yürütülen lisansüstü tez performansının da kadın akademisyenlere kıyasla daha yüksek olduğu söylenebilir. Bununla birlikte bu performansın unvan siralamasina uygun olarak da siralandığ 1 ifade edilebilir. Diğer yandan turizm dişı birimlerde görev yapan akademisyenlerin yayın ortalamalarının turizm birimlerindeki akademisyenlere kıyasla düşük olduğu belirtilebilir. Turizm alanındaki akademisyenler tarafından çalışılan konular incelendiğinde ise Doç. Dr. unvanlı akademisyenlerin rehberlik alanında çalışma yapmaya daha fazla yöneldikleri ve 


\section{IIIII)}

Turist Rehberliği Dergisi (TURED) \& Y1l. 2021, Cilt. 4, Sayı. 2

Journal of Tour Guiding (JOTOG) \& Year. 2021, Volume. 4, Issue. 2

erkek akademisyenlerin çalışmalarında rehberlik alanına daha fazla yoğunlaştıkları söylenebilir.

Araştırmada elde edilen bulgular ve çıkan sonuçlar ile ilgili olarak ilgili taraflara ve bundan sonra araştırma yapacaklara birtakım öneriler getirilebilir. Söz konusu öneriler aşağıda sıralanmıştır:

- Üniversitelerde "Dinler Tarihi”, "Sanat Tarihi”, “Türkiye'nin Turizm Coğrafyası”, "Genel Sağlık Bilgisi ve İlk Yardım”, "İletişim Becerileri” gibi rehberlik eğitimi ve rehberlik uygulamaları için önem arz eden bazı derslerin ilgili üniversitelerin müfredatlarında zorunlu ders olarak yer alması sağlanabilir.

- Müfredatlarında bitirme projesi olan bazı üniversitelerde bitirme projelerinin yazılması sürecinde zorluk yaşanmasının önüne geçilebilmesi ve dolayısıyla program dâhilinde nitelikli projelerin ortaya çıkabilmesi için "Bilimsel Araştırma Yöntemleri ve Yayın Etiği”" dersinin ilgili üniversitelerin müfredatlarına eklenmesi önerilebilir.

- Özellikle "Mitoloji”, "Sanat Tarihi”, “Arkeoloji”, "Dinler Tarihi” gibi uzmanlık gerektiren derslerde başka birimlerden bu alanlarda uzmanlığı bulunan akademisyenlerin ağırlıklı olarak görevlendirilmeleri ile lisansüstü düzeydeki rehberlik eğitiminin kalitesi artırılabilir.

- Turizm alanındaki akademisyenlerin genel olarak yayın ortalamalarının turizm alanı dışındaki birimlerde görevli akademisyenlerden yüksek olması 1şığında turizm dışı birimlerdeki akademisyenlerin rehberlik programları dâhilindeki ders görevlendirilmelerinde idari görevlerinden ziyade uzmanlık alanları ile birlikte yayın performansları da dikkate alınabilir.

- Lisans alanı "Turizm Rehberliği” olan akademisyenlerin rehberlik programlarında sayısının artırılması ve dolayısıyla tezsiz yüksek lisans düzeyinde rehberlik alanındaki akademisyenler tarafindan yürütülen ders sayısının artırılması sağlanabilir.

- Üniversitelerde rehberlik alanında lisansüstü eğitim veren akademisyenlerin rehberlik alanında yapılan yayınlarının nicelik olarak artırılması desteklenerek teşvik edilebilir.

- $\mathrm{Bu}$ araştırma sadece tezsiz yüksek lisans düzeyinde eğitiminin sürdürüldüğü “Turist Rehberliği” ve "Turizm Rehberliği” programları üzerinde gerçekleştirildiği için tüm rehberlik programlarına genellenemese de farklı programlar üzerinde gerçekleştirilecek araştırma sonuçları ile karşılaştırılabilir.

- Gelecekteki araştırmalar için bir diğer öneri, rehberlik alanında tezli yüksek lisans eğitimi ile tezsiz yüksek lisans eğitiminde ders yürüten akademisyenler bağlamında farklılıkların olup olmadığının araştırılmasıdır.

Sonuç olarak 2020-2021 akademik y1lında Türkiye'deki "Turist/Turizm Rehberliği”" tezsiz yüksek lisans programlarında yürütülen dersler ve ders yürüten akademisyenlerin incelenmesi neticesinde turist rehberliği tezsiz yüksek eğitiminin mevcut durumunun yansıtıldığı ve tartışıldığı bu araştırmanın özellikle tezsiz yüksek düzeyindeki rehberlik eğitiminin ve bu eğitimde görev alan akademisyenlerin tespiti üzerine fayda sağlayacağ düşünülmektedir. 


\section{Kaynakça}

3. Turizm Şûrası. (2017). Turizm eğitimi, istihdamı ve turist rehberliği komisyon raporu (Turizm eğitimi, istihdamı ve turist rehberliği komisyonu). https://turizmsurasi.ktb.gov.tr/Eklenti/57389, turizmegitimiistihdamituristrehberligikomis yonraporupdf.pdf, Erişim Tarihi: 2 Temmuz 2021.

Ahipaşaoğlu, S. (2006). Turizmde rehberlik (2. Baskı). Gazi Kitapevi.

Albuz, N., Ercan, F., Köşker, H. \& Özbek, Ö. (2018). 2017 yılı turist rehberliği ön lisans ve lisans eğitimine yönelik değerlendirmeler. İçinde N. Hacıoğlu, C. Avcıkurt, A. Kılıç \& H. Ulusoy Y1ldırım (Ed.), Turist rehberliği üzerine güncel araştırmalar (ss. 78-93). Detay Yayıncilik.

Ap, J. \& Wong, K. K. (2001). Case study on tour guiding: Professionalism, issues and problems. Tourism Management, 22(5), 551-563.

Aylan, S. \& Başoda, A. (2018). Türkiye'de turist rehberliği lisans programlarındaki akademik personel istihdamının değerlendirilmesi. İçinde N. Hacıoğlu, C. Avcıkurt, A. Kılıç \& H. Ulusoy Yıldırım (Ed.), Turist rehberliği üzerine güncel araştırmalar (ss. 132-154). Detay Yayıncilik.

Başoda, A. \& Aylan, S. (2018). Türkiye'de turist rehberliği lisans programlarının sayısal açıdan yapısal ve coğrafik değerlendirilmesi. İçinde N. Hacıoğlu, C. Avcıkurt, A. Kılıç \& H. Ulusoy Yıldırım (Ed.), Turist rehberliği üzerine güncel araştırmalar (ss. 94-113). Detay Yayıncilik.

Bayram, G. E., Karaçar, E. \& Bayram, A. T. (2017). The importance of ecotourism consciousness on tour guiding education. Journal of Research in Education and Teaching, 3, 40-50.

Baytok, A., Boyraz, M. \& Kabakulak, A. (2019). Turizm/turist rehberliği bölümü akademisyenlerinin profili: Türkiye üniversiteleri örneği. Uluslararası Sosyal Araştırmalar Dergisi, 12(68), 1038-1049.

Boyraz, M. \& Kabakulak, A. (2020). Türkiye'deki turizm rehberliği bölümlerinde görev yapan akademisyenlerin bilimsel yayınlarının bibliyometrik analizi. Türk Turizm Araştırmaları Dergisi, 4(3), 2152-2163.

Çakmak, T. F. \& Dinçer, F. İ. (2018). Turist rehberliği bölümleri ders programlarının "Türk kimliği" açısından incelenmesi. International Journal of Contemporary Tourism Research, 2(2), 67-75.

Çokişler, N. (2017). Turizm rehberliği eğitiminde çeyrek asırdır değişmeyen parçalanmış yapı sorunu. İçinde 3. Turizm Şurası Tebliğler Kitabı Cilt 2 (ss. 325-335).

Çolakoğlu, O. E., Efendi, E. \& Epik, F. (2017). Tur yönetimi ve turist rehberliği (4. Bask1). Detay Yayıncilik.

Demirbulat, Ö. G., Aymankuy, Y., Karagöz, İ. C. \& Aymankuy, Ş. (2018). Türkiye'de lisans düzeyindeki turizm rehberliği bölümlerinde görev yapan akademisyenlerin akademik özgeçmişlerinin incelenmesi. Akademik Sosyal Araştırmalar Dergisi, 6(70), 355-367.

Doğancılı, O. S. \& Karaçar, E. (2018). Turizm rehberliği bölümünde bulunan akademisyenlerin Yök akademik profillerinin incelenmesi. İçinde Y. Çobanoğlu (Ed.), Sosyal, beşeri ve idari bilimler alanında akademik çalışmalar (Cilt I) (ss. 83-94). Gece Kitaplığ1.

Eker, N., Kaya, M. C. \& Zengin, B. (2019). Turist rehberliği eğitimi. İçinde B. Zengin, G. E. Bayram ve O. Batman (Ed.), Turist rehberliği mesleği (Dünü-Bugünü-Yarını) (ss. 59-93). Detay Yayıncilik.

Eker, N. \& Zengin, B. (2016). Turizm rehberliği eğitimi müfredatlarının uygulama yeterliliğinin profesyonel turist rehberleri bakış açısıyla irdelenmesi. Turizm ve Araştırma Dergisi, 5(2), 4-19. 
Eser, S. (2020). Lisansüstü turizm rehberliği eğitimi üzerine bir durum analizi. Journal of Tourism and Gastronomy Studies, 8(4), 2956-2984.

Güven, Ö. Z. \& Ceylan, U. (2014). Lisans ve ön lisans düzeyinde turizm rehberliği eğitimi veren okullardaki müfredatların turizm rehberliği meslek yönetmeliğine uygunluğunun incelenmesi. İçinde A. Kılıçlar (Ed.), 15. Ulusal Turizm Kongresi Bildiriler Kitabı (ss. 186195).

İşçeli, Z. \& Kılıç, G. (2018). Lisans düzeyinde turizm rehberliği eğitimi veren fakültelerin müfredatlarının incelenmesi. Turist Rehberliği Dergisi, 1(1), 41-56.

Kabakulak, A. \& Boyraz, M. (2020). Turist rehberi akademisyenlerin bilimsel yayınlarının veri görselleştirme tekniği ile bibliyometrik analizi. Uluslararası Türk Dünyası Turizm Araştırmaları Dergisi, 5(2), 230-245.

Kürkçü, M. (2018). Rehber adayları gözünden turist rehberliği bölümleri ders programları ve uygulamalardaki yanlışliklar. Mediterranean Journal of Humanities, 8(2), 437-449.

Lovrentjev, S. (2015). Education of tourist guides: Case of Croatia. Procedia Economics and Finance, 23, 555-562.

Sezerel, H. \& Özoğul, T. (2019). Öğrenciyi merkeze almak: Turist rehberliği eğitiminde uzman mantosu yaklaşımı. Dokuz Eylül Üniversitesi Işsletme Fakültesi Dergisi, 20(1), 167197.

Temizkan, R. \& Timur, B. (2021). Türkiye'deki turist rehberliği eğitim modellerinin karşılaştırmalı bir analizi. Türk Turizm Araştırmaları Dergisi, 4(4), 3550-3569.

Temizkan, S. P. \& Ergün, B. (2018). Türkiye'de turist rehberliği öğretiminin değerlendirilmesi. Turist Rehberliği Dergisi, 1(2), 95-104.

Temizkan, S. P. \& Ergün, B. (2021). Turist rehberliği öğretimi kalite ölçeği geliştirilmesi. Türk Turizm Araştırmaları Dergisi, 4(4), 3720-3739.

Tolga, Ö., Korkmaz, H. \& Atay, L. (2015). Lisans düzeyindeki turist rehberliği öğrencilerinin mesleki tutumlarına yönelik bir araştırma. Seyahat ve Otel Iş̧letmeciliği Dergisi, 12(2), 2641.

Topsakal, Y. (2021). Lisansüstü düzeyde turist/turizm rehberliği eğitimi veren programların müfredatlarının incelenmesi ve öneriler. Ankara Hacı Bayram Veli Üniversitesi Turizm Fakültesi Dergisi, 24(1), 99-115.

Turist Rehberliği Meslek Kanunu (2012). https://www.resmigazete.gov.tr/eskiler/2012/06/20120622-2.htm, Erişim Tarihi: 20 Haziran 2021.

Turist Rehberliği Meslek Yönetmeliği (2014). https://teftis.ktb.gov.tr/TR-264061/turistrehberligi-meslek-yonetmeligi.html, Erişim Tarihi: 20 Haziran 2021.

Yenipınar, U. \& Çınar, B. (2018). Turizm rehberliği lisansüstü eğitiminin akademisyenler ve profesyonel turist rehberlerinin bakış açısıyla değerlendirilmesi. İçinde N. Hacıoğlu, C. Avcıkurt, A. Kılıç \& H. Ulusoy Yıldırım (Ed.), Turist rehberliği üzerine güncel araştırmalar (ss. 114-131). Detay Yayıncılık.

Yenipinar, U. \& Kardaş, K. (2019). Turizm Rehberliği bölümleri müfredat geliştirme önerisi. Journal of Travel and Tourism Research, 14, 1-26.

Yenipınar, U. \& Zorkirişci, A. (2013). Türkiye ve Avrupa Birliği ülkelerinde turist rehberliği eğitimi. Çă̆ Üniversitesi Sosyal Bilimler Dergisi, 10(2), 111-136.

Yükseköğretim Kurulu Atlası (2021). https://yokatlas.yok.gov.tr, Erişim Tarihi: 20 Haziran 2021. 
Turist Rehberliği Dergisi (TURED) \& Yıl. 2021, Cilt. 4, Sayı. 2

Journal of Tour Guiding (JOTOG) \& Year. 2021, Volume. 4, Issue. 2

\section{ETIK ve BILLIMSEL ILLKELER SORUMLULUK BEYANI}

Bu çalışmanın tüm hazırlanma süreçlerinde (veri toplama, yazım vb.), tüm etik kurallara ve bilimsel atıf gösterme ilkelerine riayet edildiğini, herhangi bir hataya mahal vermemek için yayımdan önce makalenin bir intihal programı aracılığıyla da kontrol edildiğini yazarlar beyan eder. Ayrıca yazarlar aşağıda sıralanan hususları kabul etmiştir:

1. Calışmada yer alan ve kullanılan tüm kaynaklara, bilimsel araștırma yöntemleri ve etik ilkeler doğrultusunda atıf yapılmıştır

2. Çalışmada tüm yazarların akademik-bilimsel olarak doğrudan ve ortak katkısı vardır.

3. Bu çalışma, yazarların özgün bir çalıșmasıdır.

4. Bütün yazarlar dergiye gönderilen makaleyi görmüș ve sonuçlarını onaylamıștır.

5. Çalışmada kullanılan denek/deneklere ilişkin herhangi bir etik ihlal yapılmamış, kullanılan tüm veri toplama yöntemlerinde bilimsel etik ilkelere göre hareket edilmiștir.

6. Çalışma daha önceden bilimsel bir toplantıda sunulan özet veya bu çalışmanın daha kısa hali ise, makalede bu durum belirtilmiștir.

7. Çalıșmada, hiçbir suç unsuru veya kanuna aykırı ifade bulunmamakla birlikte, araştırma yapılırken kanuna aykırı herhangi bir yöntem kullanılmamış olup, çalışma ile ilgili tüm yasal izinler alınmış ve etik kurallara uygun hareket edilmiştir.

Aksi bir durumun tespiti halinde Turist Rehberliği Dergisi’nin hiçbir sorumluluğu olmayıp, tüm sorumluluk makale yazarlarına aittir.

Tarih : :05/11/2021

Sorumlu Yazar : Serkan AK 